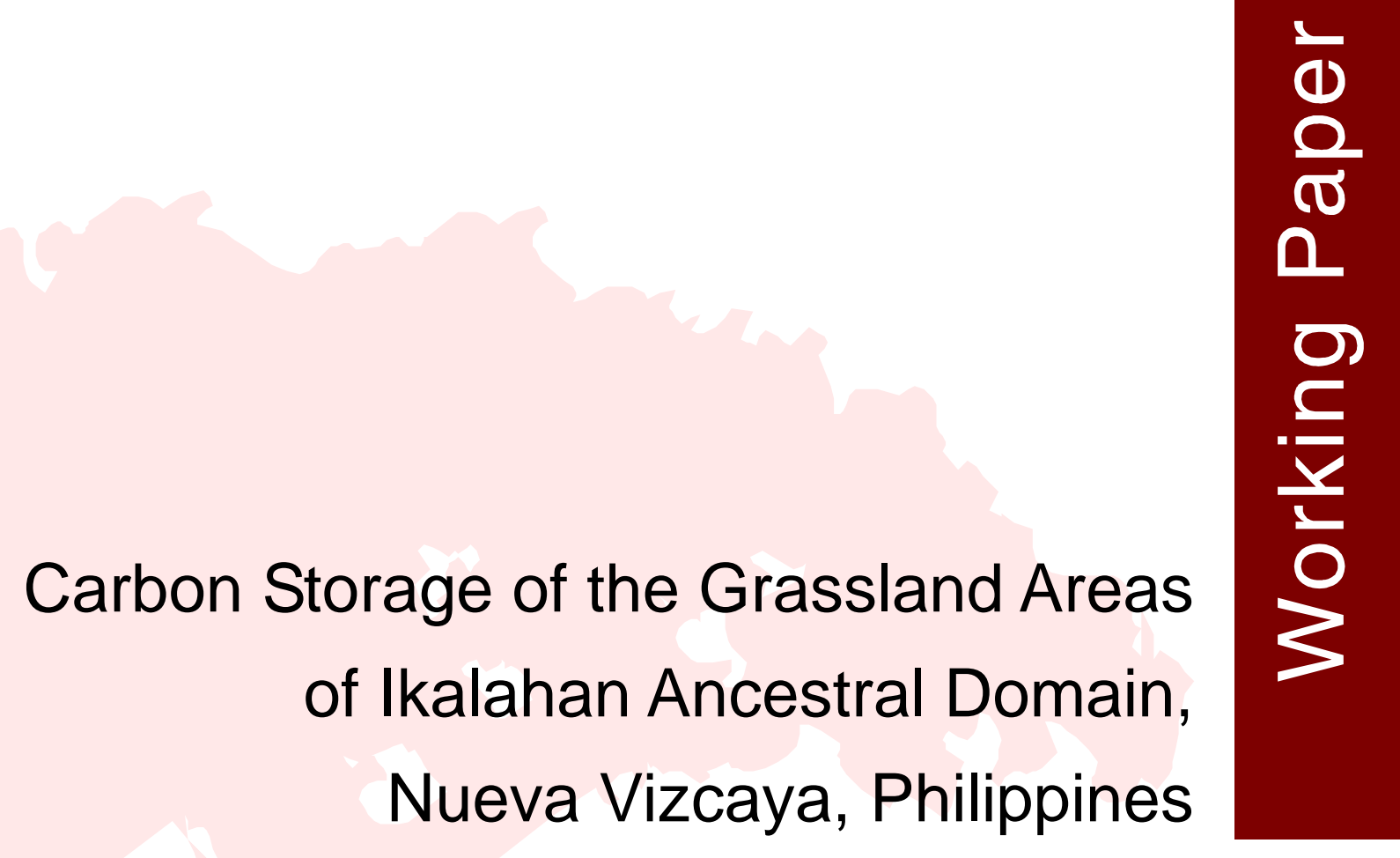

Florencia Pulhin 


\section{Carbon Storage of the Grassland Areas of Ikalahan Ancestral Domain, Nueva Vizcaya, Philippines}

Florencia Pulhin

Working Paper nr 74 


\section{(7) \\ World Agroforestry Centre \\ TRANSFORMING LIVES AND LANDSCAPES}

\section{Correct citation:}

V Pulhin, F.2008. Carbon Storage of the Grassland Areas of Ikalahan Ancestral Domain, Nueva Vizcaya, Philippines. G. Villamor (ed). WP number 74. Bogor, Indonesia, World Agroforestry Centre - ICRAF, SEA Regional Office, 32p.

Titles in the Working Paper Series aim to disseminate interim results on agroforestry research and practices and stimulate feedback from the scientific community. Other publication series from the World Agroforestry Centre include: Agroforestry Perspectives, Technical Manuals and Occasional Papers.

Published by World Agroforestry Centre

Transforming Lives and Landscapes

ICRAF Southeast Asia Regional Office

Jl. CIFOR, Situ Gede, Sindang Barang, Bogor 16680

PO Box 161, Bogor 16001, Indonesia

Tel: 62251 625415, fax: 62251625416

Email: icraf-indonesia@cgiar.org

ICRAF Southeast Asia website: http://www.worldagroforestrycentre.org/sea

Working Paper 74

The views expressed in this publication are those of the author(s) and not necessarily those of the World Agroforestry Centre.

Articles appearing in this publication may be quoted or reproduced without charge, provided the source is acknowledged.

All images remain the sole property of their source and may not be used for any purpose without written permission of the source.

\section{Disclaimer for copyright page:}

This text is a 'working paper' reflecting research results obtained in the framework of ICRAF Southeast Asia project. Full responsibility for the contents remains with the authors. 
Abbreviations

$\begin{array}{ll}\text { ABD } & \text { Bulk density } \\ \text { CDM } & \text { Clean Development Mechanism } \\ \text { DW } & \text { Dry weight } \\ \text { IFAD } & \text { International Fund for Agricultural Development } \\ \text { KEF } & \text { Kalahan Educational Foundation } \\ \text { ODW } & \text { Oven-dry weight } \\ \text { RUPES } & \text { Rewarding Upland Poor for Environmental Services they provide } \\ \text { SFW } & \text { Sample fresh weight } \\ \text { SOC } & \text { Soil organic content } \\ \text { SODW } & \text { Sample oven-dry weight } \\ \text { TFR } & \text { Total fresh weight }\end{array}$




\section{Table of Content}

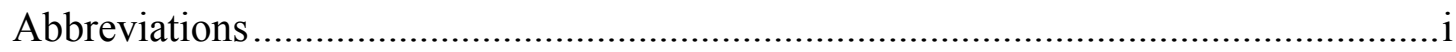

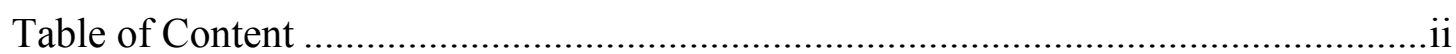

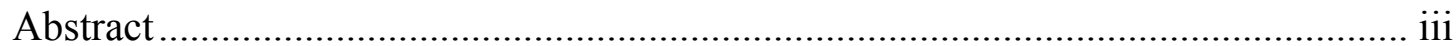

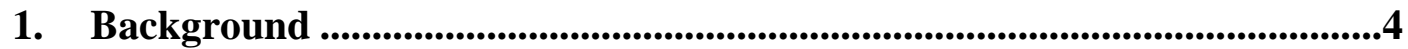

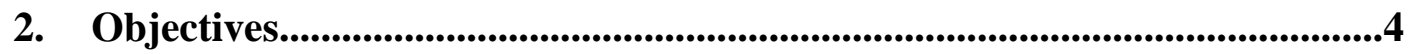

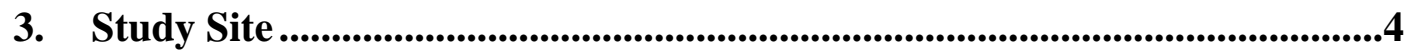

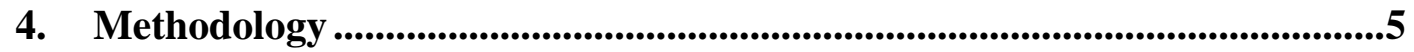

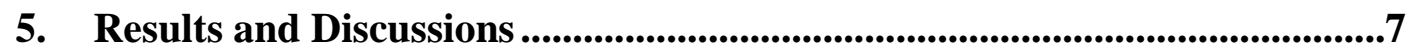

6. Implication carbon mitigation efforts ................................................................13

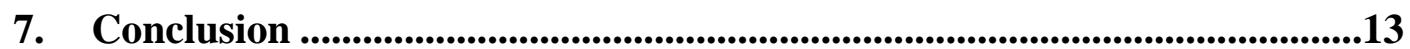

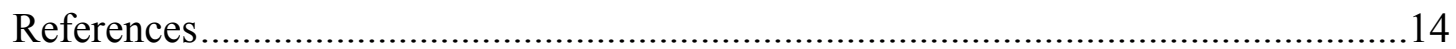

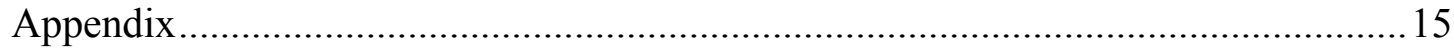

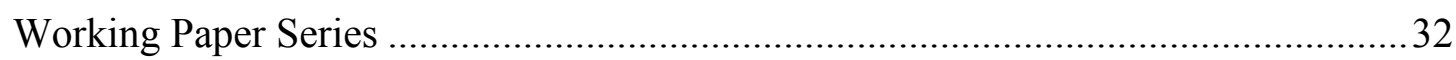




\section{Abstract}

Sample plots measuring $1 \mathrm{~m} \times 1 \mathrm{~m}$ were established in the 11 sites of the Ikalahan Ancestral Domain, Nueva Vizcaya, Philippines. Grass samples inside the plots were collected, weighed and oven dried for biomass density determination and carbon content analysis. Likewise, soil samples within the sample plots are collected to assess the bulk and carbon densities of the mentioned ecosystem. Results of the study show that biomass density of the grasslands in the area ranges from $2.75 \mathrm{Mg} / \mathrm{ha}$ to $11.60 \mathrm{Mg} / \mathrm{ha}$ or an average of $6.60 \mathrm{Mg} / \mathrm{ha}$. In terms of carbon content, carbon analysis of the grass samples indicate that grassland areas in the Domain contain around $34 \%$ carbon. Soils in the grasslands have carbon density values ranging from $35.36 \mathrm{Mg} / \mathrm{ha}$ to $47.22 \mathrm{Mg} / \mathrm{ha}$. On the average, carbon density of the grassland areas amounts to $41.42 \mathrm{Mg} / \mathrm{ha}$. Total carbon density of the grassland areas ranges from $36.59 \mathrm{Mg} / \mathrm{ha}$ to 52

$\mathrm{Mg} / \mathrm{ha}$. Average total carbon density of the grasslands is about $44 \mathrm{Mg} / \mathrm{ha}$. In terms of percentage, analysis shows that a large percentage of the total carbon density of the grasslands is found in the soil. This carbon pool contributes around $91-99 \%$ of the total carbon density. On the other hand, the grass component contributes a very small percentage of a mere $1-9 \%$. Results indicate that soil is a major sink of carbon because it does not only absorb large amount of carbon but it also holds carbon for a longer period of time compared with vegetation. 


\section{Background}

A study of the carbon storage of the grassland areas in Ikalahan Ancestral Domain was commissioned to an independent body in 2006 to assist the Kalahan Educational Foundation (KEF) to participate in the carbon market particularly for the Clean Development Mechanism (CDM). The purpose of this study is to assess the carbon storage of the grassland areas in the Domain. The main result of the study has three parts: 1) biomass densities of the grassland; 2) carbon content of the grassland area and soil organic content; and 3) total carbon densities. The study was funded by the International Fund for Agricultural Development (IFAD) under the Rewarding Upland Poor for providing Environmental Services (RUPES) Project Phase 1.

\section{Objectives}

- To determine the biomass density of the grassland areas in Kalahan;

- To ascertain the carbon content of the grass samples collected;

- To find out the carbon density of the soils in grasslands; and

- To estimate the total carbon density of the grassland.

\section{Study Site}

The study was conducted inside the Ikalahan Ancestral Domain, Nueva Vizcaya in the northern part of the Philippines with a total area of 50,000 ha. The target areas are grassland areas in 11 barangays or villages (table 1). All the sampled barangays are located at N16 ${ }^{\circ} 120^{\prime} E$ with elevation ranging from 500-1300 masl.

The domain is one of the pilot sites of RUPES project in the Philippines. Under the project, RUPES Kalahan team examines and tests payments from carbon sequestration, biodiversity and watershed protection. 
Table 1. Site profile of the sampled sites.

\begin{tabular}{|c|c|c|c|}
\hline $\begin{array}{c}\text { SITE } \\
\text { (barangays) }\end{array}$ & LOCATION & $\begin{array}{l}\text { ELEVATION } \\
\text { (masl) }\end{array}$ & SPECIES PRESENT \\
\hline 1. Buyasyas & $\mathrm{N} 16^{0} 120^{\prime} \mathrm{E}$ & 992.25 & $\begin{array}{l}\text { Cogon, Malatungao, Talahib, Talnag, } \\
\text { Tiger grass }\end{array}$ \\
\hline 2. Canabuan & $\mathrm{N} 16^{0} 120^{\prime} \mathrm{E}$ & 673.5 & $\begin{array}{l}\text { Cogon, Dilang baka, Hagonoi, } \\
\text { Malatungao, Napier, Tambo }\end{array}$ \\
\hline 3. Canarem & $\mathrm{N} 16^{0} 120^{\prime} \mathrm{E}$ & 614.25 & $\begin{array}{l}\text { Bayabas, Cogon, Hagonoi, } \\
\text { Malatungao, Malvaceae sp. }\end{array}$ \\
\hline 4. Anayo & $\mathrm{N} 16^{0} 120^{\prime} \mathrm{E}$ & 592.5 & $\begin{array}{l}\text { Carabao grass, Cogon, Coronitas, } \\
\text { Dilang baka, Dilang-aso, Guava, } \\
\text { Hagonoi, Kalmot pusa, Kudzu, } \\
\text { Malatungao, Napier }\end{array}$ \\
\hline 5. Balete, Sta. Fe & $\mathrm{N} 16^{0} 120^{\prime} \mathrm{E}$ & 673.25 & Cogon, Malatungao, Talahib \\
\hline 6. Balete, Aritao & N16 ${ }^{0} 120^{\prime} \mathrm{E}$ & 541.5 & $\begin{array}{l}\text { Bayanti, Carabao grass, Cogon, } \\
\text { Coronitas, Guava, Hagonoi, Ladao, } \\
\text { Lantana, Malatungao, Tibig, Talahib, } \\
\text { Wild oregano }\end{array}$ \\
\hline 7. Tactac & $\mathrm{N} 16^{0} 120^{\prime} \mathrm{E}$ & 893 & $\begin{array}{l}\text { Carabao grass, Cogon, Guava, Kalmot } \\
\text { pusa, Talahib }\end{array}$ \\
\hline 8. Atbu & $\mathrm{N} 16^{0} 120^{\prime} \mathrm{E}$ & 836 & $\begin{array}{l}\text { Cogon, Coronitas, Dilang aso, Guava, } \\
\text { Hagonoi, Hauili, Ladao, Malatungao, } \\
\text { Napier grass, Talahib }\end{array}$ \\
\hline 9. Sta. Rosa & $\mathrm{N} 16^{0} 120^{\prime} \mathrm{E}$ & 1350.5 & $\begin{array}{l}\text { Benguet pine, Cogon, Malatungao, } \\
\text { Napier grass, Pteridaceae sp., Silver } \\
\text { fern, Talahib }\end{array}$ \\
\hline 10. Kapinyahan & $\mathrm{N} 16^{0} 120^{\prime} \mathrm{E}$ & 671.5 & Carabao grass, Cogon, Hauili, Talahib \\
\hline 11. Putlan & $\mathrm{N}^{\prime} 6^{0} 120^{\prime} \mathrm{E}$ & 514.75 & Cogon, Talahib \\
\hline
\end{tabular}

\section{Methodology}

Sample plots. Barangays with large areas of grassland were identified and established sample plots. In each barangay, two strips were laid on the ground. Each strip contained five sampling points with 50 meters interval. In each sampling points, a $1 \mathrm{~m}$ x $1 \mathrm{~m}$ frame plot was laid. All grasses inside the sampling frames were collected for biomass determination. Soil samples were collected at $30 \mathrm{~cm}$ depth. For bulk density determination, samples were collected from an undisturbed spot inside the sampling frame. A ring metal with a height of $5 \mathrm{~cm}$ and diameter of $3 \mathrm{~cm}$ was carefully pushed into the undisturbed soil and sampled the $0-5 \mathrm{~cm}$ depth layer.

Biomass values. Fresh grass samples were weighed and a sample of 300 grams from each plot was set aside for oven drying. 
Biomass values for grass were calculated using the following formula:

$$
\mathrm{ODW}=\frac{\mathrm{TFW}-\left(\mathrm{TFW}^{*}(\mathrm{SFW}-\mathrm{SODW})\right)}{\mathrm{SFW}}
$$

where,

$$
\begin{aligned}
& \text { ODW = total oven dry weight } \\
& \text { TFW = total fresh weight } \\
& \text { SFW = sample fresh weight } \\
& \text { SODW = sample oven-dry weight }
\end{aligned}
$$

Carbon density calculation. To calculate the carbon density, the following formula was used.

$$
\mathrm{C} \text { Density }=\text { Biomass Density } \mathrm{x} \% \text { Carbon }
$$

Soil carbon analysis. Soil samples were placed in labeled plastic bags, air dried and taken to the Soils Laboratory of the Soil Science Department of the College of Agriculture, University of the Philippines Los Baños for analysis. Method used for the analysis was the Walkey-Black method (PCARR, 1981).

For bulk density, samples collected were placed in aluminum foil and were taken to the laboratory for fresh weight determination and oven drying. Bulk density was computed using the following formula:

$$
\text { B. D. } \frac{=\mathrm{DW}}{\mathrm{V}}
$$

where,

$$
\begin{aligned}
& \text { B.D. }=\text { bulk density of the soil }(\mathrm{g} / \mathrm{cm} 3) \\
& \text { DW }=\text { dry weight of the soil }(\mathrm{g}) \\
& \mathrm{V}=\text { volume of the cylinder }(\mathrm{cm} 3)
\end{aligned}
$$

The dry weight of the soil and the equivalent carbon stock was determined using the following formulae:

Soil mass at specified depth $(\mathrm{Mg})$

$=$ Bulk density at specified depth $(\mathrm{Mg} / \mathrm{m} 3) \times 10,000 \mathrm{~m} 2 \times$ depth $(\mathrm{m})$

Soil carbon at specified depth $(\mathrm{Mg})$

$=$ Soil mass at specified depth $(\mathrm{Mg}) \times$ \%organic carbon at specified depth $/ 100$ 


\section{Results and Discussions}

Plant species. Cogon (Imperata cylindrica) is the most commonly found plant species in all the sites. Two other species namely malatungao and talahib (Saccharum spontaneum) are relatively common in the sites. Other species present in the area include bayanti, carabao grass (Axonopus compressus), coronitas, dilang baka, dilang-aso, guava, hagonoi, hauili, kalmot pusa, kudzu, malatungao, napier (Pennisetum purpureum), guava, hagonoi, ladao, lantana, tibig, and wild oregano.

Biomass density. The computed biomass density of grasslands in the domain ranges from $2.75 \mathrm{Mg} / \mathrm{ha}$ to $11.60 \mathrm{Mg} / \mathrm{ha}$. On the average, the area has biomass density of $6.60 \mathrm{Mg} / \mathrm{ha}$ (Table 2). Of the 11 barangays that are sampled, grasslands in Buyasyas have the highest biomass density while the lowest are found in Balete, Sta Fe area. It is worthy to note however, that grasslands in Kapinyahan have nearly the same biomass density as that of the grasslands in Buyasyas since they have on the average biomass density of $11.60 \mathrm{Mg} / \mathrm{ha}$. Biomass densities of the sampled sites are in the following order: Buyasyas $>$ Kapinyahan $>$ Canabuan $>$ Tactac $/$ Putlan $>$ Sta Rosa $>$ Anayo $>$ Canarem, $>$ Balete $($ Aritao) $>$ Atbu $>$ Balete (Sta Fe).

Compared with the biomass density values obtained from the grassland areas of the PNOC Leyte Geothermal Reservation, the domain is two to three times lower than the biomass density obtained from the grassland area of Leyte depending on the dominant species studied (Lasco et al. 1999). For example, old swards of cogon in Leyte have biomass density ranging from $8.81 \mathrm{Mg} / \mathrm{ha}$ to $14.39 \mathrm{Mg} / \mathrm{ha}$ or an average of $11.50 \mathrm{Mg} / \mathrm{ha}$. Talahib species on the other hand, has biomass density value ranging from $21.86 \mathrm{Mg} / \mathrm{ha}$ to 36.79 $\mathrm{Mg} / \mathrm{ha}$ or an average of about $27 \mathrm{Mg} / \mathrm{ha}$. Also, the obtained biomass density from this study is lower than the value reported by Fearnside (1996) for pastures and agricultural areas. Accordingly, these areas have average total biomass of $43.5 \mathrm{Mg} / \mathrm{ha}$.

On the other hand, the values obtained from this study are a lot higher when compared with biomass density values obtained from grassland ecosystem in Kaliwa watershed, Tanay, Rizal (biomass density ranging from $0.91 \mathrm{Mg} / \mathrm{ha}$ to $4.13 \mathrm{Mg} / \mathrm{ha}$ ). On the average, biomass density of grasslands in Kaliwa watershed is only $1.92 \mathrm{Mg} / \mathrm{ha}$.

Lugo and Brown (1992) mentioned that different values of biomass of a system are resulted from the different degrees of anthropogenic and natural disturbances. Grassland areas experiencing little or less disturbance exhibit higher biomass densities while areas that are frequently burned have lower biomass densities. 
Table 2. Biomass densities of the of the grassland areas in the domain.

\begin{tabular}{|l|c|}
\hline \multicolumn{1}{|c|}{ LOCATION } & BIOMASS DENSITY (Mg/ha) \\
\hline Buyasyas & 11.60 \\
\hline Canabuan & 9.02 \\
\hline Canarem & 4.32 \\
\hline Anayo & 4.92 \\
\hline Balete, Sta. Fe & 2.75 \\
\hline Balete, Aritao & 3.56 \\
\hline Tactac & 7.21 \\
\hline Atbu & 3.49 \\
\hline Sta. Rosa & 7.11 \\
\hline Kapinyahan & 11.36 \\
\hline Putlan & 7.21 \\
\hline Mean & $\mathbf{6 . 6 0}$ \\
\hline
\end{tabular}

Carbon content of grasslands. Carbon content of grass samples in the domain ranges from $22 \%$ to $40 \%$ (Table 3 ). On the average, grasslands have carbon content of $34.09 \%$. Results imply that only $34 \%$ of the grasses are carbon. Highest carbon content was obtained from the grass samples of Tactac while lowest carbon content was recorded from the samples of Balete, Sta Fe. Grass samples from Tactac and Balete, Sta Fe have mean carbon content of $39.82 \%$ and $22.02 \%$, respectively. More than half of the eleven sampled sites have carbon content of $35 \%$ or greater. These are Anayo, Tactac, Atbu, Sta Rosa, Kapinyahan and Putlan.

Compared with other studies conducted (Lasco et al. 1999), the percent carbon obtained from the plant tissues is far lower than the carbon content of grasslands of Leyte and Tanay, Rizal. Grass samples of Leyte have mean carbon content of $44 \%$ while those of Kaliwa watershed in Tanay, Rizal contain about $43.7 \%$ carbon. 
Table 3. Carbon content of the grasslands in the domain.

\begin{tabular}{|l|c|}
\hline \multicolumn{1}{|c|}{ LOCATION } & CARBON CONTENT (\%) \\
\hline Buyasyas & 31.52 \\
\hline Canabuan & 30.38 \\
\hline Canarem & 31.84 \\
\hline Anayo & 34.58 \\
\hline Balete, Sta. Fe & 22.02 \\
\hline Balete, Aritao & 34.46 \\
\hline Tactac & 39.82 \\
\hline Atbu & 39.46 \\
\hline Sta. Rosa & 37.44 \\
\hline Kapinyahan & 35.04 \\
\hline Putlan & 38.48 \\
\hline Mean & $\mathbf{3 4 . 0 9}$ \\
\hline
\end{tabular}

\section{a. Aboveground carbon density}

Similar to the trend observed in the biomass densities, grassland areas in Balete, Sta Fe have the lowest carbon density. On contrary, highest carbon density is found in the grasslands of Kapinyahan (Table 4). Grasslands in Buyasyas only rank second in terms of carbon density because the carbon content of the grass samples amounts only to $31.52 \%$. While the grass samples from Buyasyas and Kapinyahan have almost the same biomass densities, grass samples from Kapinyahan exhibit higher carbon density than that of Buyasyas because carbon content of grass samples from Kapinyahan is about $4 \%$ higher. Carbon densities of the sampled grasslands in 11 barangays do not follow the same order as the biomass densities. This is due to the varying carbon content obtained from the grass samples. Carbon densities of the sampled barangays are in the following order: Kapinyahan $>$ Buyasyas $>$ Tactac $>$ Putlan $>$ Canabuan $>$ Sta Rosa $>$ Anayo $>$ Atbu $/$ Canarem $>$ Balete $($ Aritao) $>$ Balete $(\mathrm{Sta} \mathrm{Fe})$.

Aboveground carbon density of the grassland areas in the 11 barangays range from 1.23 $\mathrm{Mg} / \mathrm{ha}$ to $3.98 \mathrm{Mg} / \mathrm{ha}$. Average carbon density in the grasslands of the domain amounts to $2.25 \mathrm{Mg} / \mathrm{ha}$. Compared to the carbon densities obtained in the grasslands of the PNOC Geothermal Leyte, calculated carbon densities from this study is a lot lower. Carbon density of cogon and talahib in Leyte is $5.11 \mathrm{Mg} / \mathrm{ha}$ and $11.45 \mathrm{Mg} / \mathrm{ha}$, respectively. Furthermore, the results of this study are inconsistent with the IPCC default value of 10 $\mathrm{Mg} / \mathrm{ha}$ for crop lands and pasture areas (IPCC, 1996). However, it is worthy to note that values obtained from this study are higher than those obtained from the grasslands of the Kaliwa watershed $(0.84 \mathrm{Mg} / \mathrm{ha})$. 
Table 4. Aboveground carbon densities of the grassland areas in the domain.

\begin{tabular}{|l|c|c|}
\hline \multicolumn{1}{|c|}{ LOCATION } & CARBON CONTENT (\%) & CARBON DENSITY (Mg/ha) \\
\hline Buyasyas & 31.52 & 3.66 \\
\hline Canabuan & 30.38 & 2.74 \\
\hline Canarem & 31.84 & 1.38 \\
\hline Anayo & 34.58 & 1.70 \\
\hline Balete, Sta. Fe & 22.02 & 0.61 \\
\hline Balete, Aritao & 34.46 & 1.23 \\
\hline Tactac & 39.82 & 2.87 \\
\hline Atbu & 39.46 & 1.38 \\
\hline Sta. Rosa & 37.44 & 2.66 \\
\hline Kapinyahan & 35.04 & 3.98 \\
\hline Putlan & 38.48 & 2.77 \\
\hline Mean & $\mathbf{3 4 . 0 9}$ & $\mathbf{2 . 2 5}$ \\
\hline
\end{tabular}

\section{b. Soil bulk and carbon densities}

The bulk densities of the soil in all the sampled sites ranged from $0.7487 \mathrm{~g} / \mathrm{cc}$ to 1.0347 $\mathrm{g} / \mathrm{cc}$. Lowest bulk density is exhibited by the grasslands in Sta Rosa while the highest bulk density is found in Balete, Sta Fe. It should be noted that almost all of the barangays sampled have bulk densities $\geq 0.9 \mathrm{~g} / \mathrm{cc}$. Representing around $82 \%$ of the total sampled areas, sites belonging to this group includes Buyasyas, Canabuan, Canarem, Anayo, Balete (Sta Fe), Balete (Aritao), Atbu, Kapinyahan, and Putlan. The remaining 18\% of the total sampled sites have soil bulk densities of $0.75 \mathrm{~g} / \mathrm{cc}$ only. This group includes Sta Rosa and Tactac (Table 5). Results indicate that soil bulk density values derived from the grasslands of the domain are relatively high. Ecosystems with high soil bulk density values indicate that such areas are disturbed and more compact which is typical characteristic of the grassland areas in the Philippines.

Table 5 further shows the percent soil organic carbon (SOC) of the grasslands of the domain. Percent SOC of the grasslands sampled range from 3.58 to 6.42. Highest percent SOC is observed in Sta Rosa while the lowest percent SOC is manifested by the grasslands in Balete, Aritao. On the average, percent SOC is valued at 4.66.

In terms of soil carbon density, soils in the grasslands of the domain have values ranging from $35.36 \mathrm{Mg} / \mathrm{ha}$ to $47.22 \mathrm{Mg} / \mathrm{ha}$. Highest SOC is found in the grasslands of Barangay Sta Rosa while the lowest SOC is revealed by those found in Barangay Balete, Sta Fe. Average carbon density of the grassland areas amounts to $41.42 \mathrm{Mg} / \mathrm{ha}$.

Compared with other studies conducted, carbon density values obtained from this study is lower than those derived from the studies conducted in Leyte and Tanay, Rizal. Soil carbon density values of the grasslands in Leyte and Tanay, Rizal are $52.70 \mathrm{Mg} / \mathrm{ha}$ and $55 \mathrm{Mg} / \mathrm{ha}$, respectively. 
Table 5. Soil bulk and carbon densities of grassland areas in the domain

\begin{tabular}{|l|c|c|c|}
\hline \multicolumn{1}{|c|}{ LOCATION } & $\begin{array}{c}\text { BULK DENSITY } \\
\text { (g/cc) }\end{array}$ & SOC (\%) & $\begin{array}{c}\text { CARBON DENSITY } \\
\text { (Mg/ha) }\end{array}$ \\
\hline Buyasyas & 0.8920 & 4.43 & 38.71 \\
\hline Canabuan & 0.9476 & 4.01 & 37.92 \\
\hline Canarem & 1.0022 & 4.42 & 44.20 \\
\hline Anayo & 0.8973 & 5.12 & 45.78 \\
\hline Balete, Sta. Fe & 1.0347 & 5.00 & 35.48 \\
\hline Balete, Aritao & 0.9870 & 3.58 & 41.32 \\
\hline Tactac & 0.7501 & 5.51 & 37.69 \\
\hline Atbu & 0.8866 & 4.24 & 47.22 \\
\hline Sta. Rosa & 0.7487 & 6.42 & 40.02 \\
\hline Kapinyahan & 0.8653 & 4.64 & 35.90 \\
\hline Putlan & 0.9271 & 3.89 & $\mathbf{4 1 . 4 2}$ \\
\hline & $\mathbf{0 . 9 0 3 5}$ & $\mathbf{4 . 6 6}$ & \\
\hline
\end{tabular}

\section{c. Total carbon density}

Figure 1 shows the total carbon density of the grassland areas in the domain. Of the 11 sampled sites, grasslands in Balete, Sta Fe are found to have the highest carbon density around $52 \mathrm{Mg} / \mathrm{ha}$. Lowest total carbon density is found Balete, Aritao amounting to 36.59 $\mathrm{Mg} / \mathrm{ha}$. Average total carbon density of the grasslands in the Domain is about $44 \mathrm{Mg} / \mathrm{ha}$. The 11 barangays sampled are in the following order in terms of total carbon density: Balete, Sta Fe $>$ Sta Rosa $>$ Anayo $>$ Canarem $>$ Tactac $>$ Kapinyahan $>$ Buyasyas $>$ Canabuan $>$ Atbu $>$ Putlan $>$ Balete, Aritao.

Compared with the total carbon density values derived from the PNOC Geothermal Reservation in Leyte and the Kaliwa watershed in Tanay, Rizal, values obtained from this study is lower. Total carbon density of grasslands in the PNOC Geothermal Leyte amounts to $63.53 \mathrm{Mg} / \mathrm{ha}$ while value obtained from Kaliwa watershed in Tanay, Rizal is 55.84 $\mathrm{Mg} / \mathrm{ha}$.

Percent contribution of the grass and soil components to the total carbon density of the grasslands of the domain is shown in Table 6. Results indicate that bulk of the total carbon density of the grassland areas is contributed by the soil. As shown in Table 5, soil contributes around $91-99 \%$ of the total carbon density while the grass samples contribute a mere $1-9 \%$. Results obtained are consistent with the results derived from the other studies conducted. For instance, in the studies conducted in Leyte total carbon density attributed by the soil is around $83 \%$ while only $17 \%$ is contributed by the aboveground carbon pool. In Tanay, Rizal on the other hand, $98 \%$ of the total carbon density is provided by the soil and a very small percentage of two percent is given by the grass samples. Results indicate that soil is really a significant sink of carbon because compared with vegetation, soil stores more organic carbon and holds it at longer periods of time. 
The capacity of the soil to store soil organic carbon is influenced by a number of factors. These include: (1) mean annual precipitation; (2) degree of forest disturbance; and (3) extent of land use change (Lugo and Brown, 1993). According to Birdsey (1992), conversion of forests to agriculture production reduces carbon content by 40 percent.

To enhance the role of soil in carbon sequestration, Dixon et. al. (1993) recommended a number of strategies. These were: 1) forestation to reduce erosion; (2) maintaining or improving soil fertility; (3) concentrating on tropical agriculture and reducing shifting agriculture; (4) removing marginal lands from agricultural production; and (5) retaining forest litter and debris after silvicultural or logging activities.

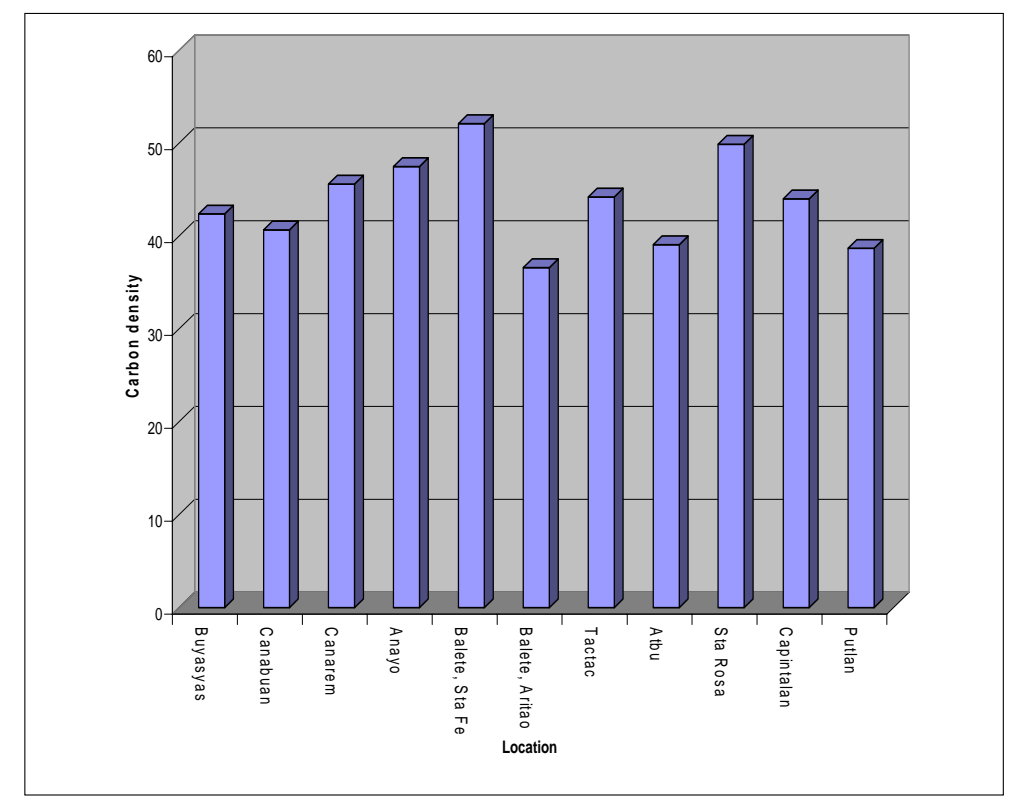

Figure 1. Total carbon density of grassland areas in the domain.

Table 6. Percent contribution of the grass and soil to the total carbon density of the grasslands in the domain.

\begin{tabular}{|l|c|c|c|c|c|}
\hline \multirow{2}{*}{ LOCATION } & \multicolumn{5}{c|}{ CARBON DENSITY } \\
\cline { 2 - 6 } & GRASS & PERCENT & SOIL & PERCENT & TOTAL \\
\hline Buyasyas & 3.66 & 8.64 & 38.71 & 91.36 & 42.37 \\
\hline Canabuan & 2.74 & 6.74 & 37.92 & 93.26 & 40.66 \\
\hline Canarem & 1.38 & 3.03 & 44.2 & 96.97 & 45.58 \\
\hline Anayo & 1.7 & 3.58 & 45.78 & 96.42 & 47.48 \\
\hline Balete, Sta Fe & 0.61 & 1.17 & 51.48 & 98.83 & 52.09 \\
\hline Balete, Aritao & 1.23 & 3.36 & 35.36 & 96.64 & 36.59 \\
\hline Tactac & 2.87 & 6.49 & 41.32 & 93.51 & 44.19 \\
\hline Atbu & 1.38 & 3.53 & 37.69 & 96.47 & 39.07 \\
\hline Sta Rosa & 2.66 & 5.33 & 47.22 & 94.67 & 49.88 \\
\hline Kapinyahan & 3.98 & 9.05 & 40.02 & 90.95 & 44 \\
\hline Putlan & 2.77 & 7.16 & 35.9 & 92.84 & 38.67 \\
\hline
\end{tabular}




\section{Implication carbon mitigation efforts}

Based on the results obtained from the study, grassland areas in the domain store very small amount of carbon. Thus, they do not significantly contribute to carbon sequestration since they undergo a cycle of grass-fire-grass cycle. Most often, grasslands in the Philippines are burned thereby releasing huge amount of carbon into the atmosphere. Unless this ecosystem is protected and properly managed, grassland cannot at all contribute in mitigating climate change in the Philippines.

To enhance the role of the grasslands in the domain in terms of carbon sequestration, they should be developed to tree plantations or agroforestry areas. Based on the results of the studies conducted on the various land uses in the Philippines, tree plantations and agroforestry systems have carbon densities of $232.97 \mathrm{MgC} / \mathrm{ha}$ (Lasco et al, 2000) and $181.46 \mathrm{MgC} / \mathrm{ha}$ (Zamora,1999), respectively. If these grassland areas are converted either into tree plantation or agroforestry, this ecosystem will definitely store huge amount of carbon. Thus, if the local communities managing the domain decide to get involved in the CDM forestry project, they will be able to gain considerable carbon credits since carbon in tree plantations and agroforestry areas are far higher than the carbon in the grasslands (baseline).

\section{Conclusion}

Prior to the implementation of a carbon sink project, carbon under the baseline condition must be assessed first. This is to ensure that additionality will occur once such project is carried out. In Ikalahan Ancestral Domain, vast tract of grassland areas are available for development of reforestation or agroforestry project. Such project can be given financing under the scheme of the CDM if found eligible. Thus, this study is done to assess the carbon storage of the grassland areas in the domain.

In conclusion, grasslands in the domain store some amount of carbon in their biomass and soil. However, potential of the area to store and sequester more carbon can be achieved if these areas are converted into tree plantations or agroforestry farms. Based on estimates, tree plantations and agroforestry systems in the Philippines have carbon densities five to six times more than the grasslands. 


\section{References}

Birdsey, R. A. 1992. Carbon Storage and Accumulation in the United States Forest Ecosystems. USDA Forest Service. General Technical Report WO-59.

Dixon, R. K., K. J. Andrasko, F. G. Sussman, M. A. Lavinson, M. C. Trexler and T. S Vinzon. 1993. The Forest Sector Carbon Offset Projects: Near Term Opportunities to Mitigate Greenhouse Gas Emission. Water, Air and Soil Pollution 70:561-577.

Fearnside, P. M. 1999. Burning of Amazonian rainforests: Burning Efficiency and charcoal formation in forest cleared for cattle pasture near Manaus, Brazil. Submitted to Forest Ecology and Management.

IPCC. 1996. Climate change. Cambridge University Press. Cambridge, UK.

Lasco, R. D., J. Sales, M. T. Arnuevo, and I. Q. Guillermo. 1999. Carbon Dioxide Absorption and Sequestration in the PNOC-Leyte Geothermal Reservation. Final Report. Environmental Forestry Programme. College of Forestry and Natural Resources, University of the Philippines Los Baños, College, Laguna.

Lasco, R.D., R.G. Visco, and J.M. Pulhin. 2000. Formation and transformation of secondary forests in the Philippines. Paper used as background material for the International Workshop on Tropical Secondary Forests in Asia: Perspective and Realities. April 2000. Samarinda, Indonesia, CIFOR.

Lugo, A. E. and S. Brown 1992. Tropical Forest as Sinks of Atmospheric Carbon. Forest Ecology and Management, 54:239-255.

Lugo, A. E. and Brown, 1993. Management of Tropical Soils as Sinks or Sources of Atmospheric Carbon. Plant and Soil. Kluwer Academic Publishers. Netherlands. 149:27-41.

PCARR (Philippine Council for Agriculture and Resources Research). 1980. Standard Methods of Analysis for Soil, Plant, Tissue, Water and Fertilizer. Los Baños, Laguna. PCARR,194 pp.

Zamora, D.S. 1999. Carbon dioxide (CO2) storage potential of multistory agroforestry systems in Mt. Makiling. College, Laguna, Philippines, College of Forestry and Natural Resources, UPLB. (MS thesis). 


\section{Appendix}

Table 1. Biomass and carbon densities of sampling points in grasslands of Barangay Buyasyas, Imugan, Nueva Vizcaya.

\begin{tabular}{ccccccc}
\hline $\begin{array}{c}\text { SAMPLE } \\
\text { CODE }\end{array}$ & $\begin{array}{c}\text { TOTAL } \\
\text { FRESH } \\
\text { WEIGHT } \\
\text { (Mg) }\end{array}$ & $\begin{array}{c}\text { SAMPLE } \\
\text { FRESH } \\
\text { WEIGHT } \\
\text { (Mg) }\end{array}$ & $\begin{array}{c}\text { OVEN } \\
\text { DRY } \\
\text { WEIGHT } \\
\text { (Mg) }\end{array}$ & $\begin{array}{c}\text { TOTAL } \\
\text { DRY } \\
\text { WEIGHT } \\
\text { (Mg) }\end{array}$ & $\begin{array}{c}\text { BIOMASS } \\
\text { DENSITY } \\
\text { (Mg/ha) }\end{array}$ & $\begin{array}{c}\text { CARBON } \\
\text { DENSITY } \\
\text { (Mg/ha) }\end{array}$ \\
\hline BG1 & 1850 & 225 & 175 & 1.44 & 14.39 & 6.48 \\
BG2 & 2675 & 350 & 299 & 2.29 & 22.85 & 10.28 \\
BG3 & 2075 & 250 & 198 & 1.64 & 16.43 & 7.40 \\
BG4 & 1850 & 300 & 230 & 1.42 & 14.18 & 6.38 \\
BG5 & 375 & 375 & 200 & 0.20 & 2.00 & 0.90 \\
BG6 & 300 & 300 & 220 & 0.22 & 2.20 & 0.99 \\
BG7 & 400 & 225 & 161 & 0.29 & 2.86 & 1.29 \\
BG8 & 1950 & 300 & 232 & 1.51 & 15.08 & 6.79 \\
BG9 & 1800 & 250 & 198 & 1.43 & 14.26 & 6.42 \\
BG10 & 1550 & 300 & 228 & 1.18 & 11.78 & 5.30 \\
Mean & $\mathbf{1 4 8 2 . 5 0}$ & $\mathbf{2 8 7 . 5 0}$ & $\mathbf{2 1 4 . 1 0}$ & $\mathbf{1 . 1 6}$ & $\mathbf{1 1 . 6 0}$ & $\mathbf{5 . 2 2}$ \\
\hline
\end{tabular}

Table 2. Biomass and carbon densities of sampling points in grasslands of Barangay Canabuan, Imugan, Nueva Vizcaya.

\begin{tabular}{ccccccc}
\hline $\begin{array}{c}\text { SAMPLE } \\
\text { CODE }\end{array}$ & $\begin{array}{c}\text { TOTAL } \\
\text { FRESH } \\
\text { WEIGHT } \\
\text { (Mg) }\end{array}$ & $\begin{array}{c}\text { SAMPLE } \\
\text { FRESH } \\
\text { WEIGHT } \\
\text { (Mg) }\end{array}$ & $\begin{array}{c}\text { OVEN } \\
\text { DRY } \\
\text { WEIGHT } \\
\mathbf{( M g )}\end{array}$ & $\begin{array}{c}\text { TOTAL } \\
\text { DRY } \\
\text { WEIGHT } \\
\text { (Mg) }\end{array}$ & $\begin{array}{c}\text { BIOMASS } \\
\text { DENSITY } \\
\text { (Mg/ha) }\end{array}$ & $\begin{array}{c}\text { CARBON } \\
\text { DENSITY } \\
\text { (Mg/ha) }\end{array}$ \\
\hline CG1 & 475 & 475 & 92 & 0.09 & 0.92 & 0.41 \\
CG2 & 425 & 425 & 175 & 0.18 & 1.75 & 0.79 \\
CG3 & 410 & 410 & 133 & 0.13 & 1.33 & 0.60 \\
CG4 & 875 & 300 & 138 & 0.40 & 4.03 & 1.81 \\
CG5 & 850 & 175 & 212 & 1.03 & 10.30 & 4.63 \\
CG6 & 575 & 100 & 222 & 1.28 & 12.77 & 5.74 \\
CG7 & 675 & 300 & 155 & 0.35 & 3.49 & 1.57 \\
CG8 & 2500 & 300 & 130 & 1.08 & 10.83 & 4.88 \\
CG9 & 380 & 380 & 228 & 0.23 & 2.28 & 1.03 \\
CG10 & 2350 & 200 & 362 & 4.25 & 42.54 & 19.14 \\
Mean & $\mathbf{9 5 1 . 5 0}$ & $\mathbf{3 0 6 . 5 0}$ & $\mathbf{1 8 4 . 7 0}$ & $\mathbf{0 . 9 0}$ & $\mathbf{9 . 0 2}$ & $\mathbf{4 . 0 6}$ \\
\hline
\end{tabular}


Table 3. Biomass and carbon densities of sampling points in grasslands of Barangay Canaraem, Imugan, Nueva Vizcaya.

\begin{tabular}{ccccccc}
\hline $\begin{array}{c}\text { SAMPLE } \\
\text { CODE }\end{array}$ & $\begin{array}{c}\text { TOTAL } \\
\text { FRESH } \\
\text { WEIGHT } \\
\text { (g) }\end{array}$ & $\begin{array}{c}\text { SAMPLE } \\
\text { FRESH } \\
\text { WEIGHT } \\
\text { (g) }\end{array}$ & $\begin{array}{c}\text { OVEN } \\
\text { DRY } \\
\text { WEIGHT } \\
\text { (g) }\end{array}$ & $\begin{array}{c}\text { TOTAL } \\
\text { DRY } \\
\text { WEIGH } \\
\text { T } \\
\text { (g) }\end{array}$ & $\begin{array}{c}\text { BIOMASS } \\
\text { DENSITY } \\
\text { (Mg/ha) }\end{array}$ & $\begin{array}{c}\text { CARBON } \\
\text { DENSITY } \\
\text { (Mg/ha) }\end{array}$ \\
\hline $\mathrm{CaG1}$ & 650 & 300 & 195 & 0.42 & 4.23 & 1.90 \\
$\mathrm{CaG} 2$ & 440 & 300 & 145 & 0.21 & 2.13 & 0.96 \\
$\mathrm{CaG3}$ & 640 & 300 & 228 & 0.49 & 4.86 & 2.19 \\
$\mathrm{CaG} 4$ & 440 & 300 & 172 & 0.25 & 2.52 & 1.14 \\
$\mathrm{CaG5}$ & 700 & 300 & 122 & 0.28 & 2.85 & 1.28 \\
$\mathrm{CaG6}$ & 540 & 250 & 191 & 0.41 & 4.13 & 1.86 \\
$\mathrm{CaG7}$ & 675 & 300 & 181 & 0.41 & 4.07 & 1.83 \\
$\mathrm{CaG} 8$ & 550 & 300 & 132 & 0.24 & 2.42 & 1.09 \\
$\mathrm{CaG} 9$ & 2000 & 300 & 200 & 1.33 & 13.33 & 6.00 \\
$\mathrm{CaG} 10$ & 660 & 300 & 120 & 0.26 & 2.64 & 1.19 \\
$\mathrm{Mean}$ & $\mathbf{7 2 9 . 5 0}$ & $\mathbf{2 9 5 . 0 0}$ & $\mathbf{1 6 8 . 6 0}$ & $\mathbf{0 . 4 3}$ & $\mathbf{4 . 3 2}$ & $\mathbf{1 . 9 4}$ \\
\hline
\end{tabular}

Table 4. Biomass and carbon densities of sampling points in grasslands of Barangay Anayo, Imugan, Nueva Vizcaya.

\begin{tabular}{ccccccc}
\hline $\begin{array}{c}\text { SAMPLE } \\
\text { CODE }\end{array}$ & $\begin{array}{c}\text { TOTAL } \\
\text { FRESH } \\
\text { WEIGHT } \\
\text { (g) }\end{array}$ & $\begin{array}{c}\text { SAMPLE } \\
\text { FRESH } \\
\text { WEIGHT } \\
\text { (g) }\end{array}$ & $\begin{array}{c}\text { OVEN } \\
\text { DRY } \\
\text { WEIGHT } \\
\text { (g) }\end{array}$ & $\begin{array}{c}\text { TOTAL } \\
\text { DRY } \\
\text { WEIGHT } \\
\text { (g) }\end{array}$ & $\begin{array}{c}\text { BIOMASS } \\
\text { DENSITY } \\
\text { (Mg/ha) }\end{array}$ & $\begin{array}{c}\text { CARBON } \\
\text { DENSITY } \\
\text { (Mg/ha) }\end{array}$ \\
\hline AG1 & 750 & 300 & 158 & 0.40 & 3.95 & 1.78 \\
AG2 & 375 & 300 & 189 & 0.24 & 2.36 & 1.06 \\
AG3 & 300 & 300 & 145 & 0.15 & 1.45 & 0.65 \\
AG4 & 450 & 300 & 152 & 0.23 & 2.28 & 1.03 \\
AG5 & 675 & 300 & 89 & 0.20 & 2.00 & 0.90 \\
AG6 & 475 & 300 & 129 & 0.20 & 2.04 & 0.92 \\
AG7 & 700 & 125 & 161 & 0.90 & 9.02 & 4.06 \\
AG8 & 700 & 300 & 99 & 0.23 & 2.31 & 1.04 \\
AG9 & 850 & 150 & 152 & 0.86 & 8.61 & 3.88 \\
AG10 & 1250 & 150 & 182 & 1.52 & 15.17 & 6.83 \\
Mean & $\mathbf{6 5 2 . 5 0}$ & $\mathbf{2 5 2 . 5 0}$ & $\mathbf{1 4 5 . 6 0}$ & $\mathbf{0 . 4 9}$ & $\mathbf{4 . 9 2}$ & $\mathbf{2 . 2 1}$ \\
\hline
\end{tabular}


Table 5. Biomass and carbon densities of sampling points in grasslands of Barangay Balete, Sta. Fe, Imugan, Nueva Vizcaya.

\begin{tabular}{ccccccc}
\hline $\begin{array}{c}\text { SAMPLE } \\
\text { CODE }\end{array}$ & $\begin{array}{c}\text { TOTAL } \\
\text { FRESH } \\
\text { WEIGHT } \\
\text { (g) }\end{array}$ & $\begin{array}{c}\text { SAMPLE } \\
\text { FRESH } \\
\text { WEIGHT } \\
\text { (g) }\end{array}$ & $\begin{array}{c}\text { OVEN } \\
\text { DRY } \\
\text { WEIGHT } \\
\text { (g) }\end{array}$ & $\begin{array}{c}\text { TOTAL } \\
\text { DRY } \\
\text { WEIGHT } \\
\text { (g) }\end{array}$ & $\begin{array}{c}\text { BIOMASS } \\
\text { DENSITY } \\
\text { (Mg/ha) }\end{array}$ & $\begin{array}{c}\text { CARBON } \\
\text { DENSITY } \\
\text { (Mg/ha) }\end{array}$ \\
\hline BaG1 & 125 & 125 & 92 & 0.09 & 0.92 & 0.41 \\
BaG2 & 600 & 300 & 155 & 0.31 & 3.10 & 1.40 \\
BaG3 & 375 & 300 & 212 & 0.27 & 2.65 & 1.19 \\
BaG4 & 340 & 300 & 218 & 0.25 & 2.47 & 1.11 \\
BaG5 & 425 & 300 & 172 & 0.24 & 2.44 & 1.10 \\
BaG6 & 225 & 225 & 161 & 0.16 & 1.61 & 0.72 \\
BaG7 & 350 & 300 & 160 & 0.19 & 1.87 & 0.84 \\
BaG8 & 650 & 300 & 220 & 0.48 & 4.77 & 2.15 \\
BaG9 & 590 & 300 & 200 & 0.39 & 3.93 & 1.77 \\
BaG10 & 590 & 300 & 189 & 0.37 & 3.72 & 1.67 \\
Mean & $\mathbf{4 2 7 . 0 0}$ & $\mathbf{2 7 5 . 0 0}$ & $\mathbf{1 7 7 . 9 0}$ & $\mathbf{0 . 2 7}$ & $\mathbf{2 . 7 5}$ & $\mathbf{1 . 2 4}$ \\
\hline
\end{tabular}

Table 6. Biomass and carbon densities of sampling points in grasslands of Barangay Balete, Aritao, Nueva Vizcaya.

\begin{tabular}{ccccccc}
\hline $\begin{array}{c}\text { SAMPLE } \\
\text { CODE }\end{array}$ & $\begin{array}{c}\text { TOTAL } \\
\text { FRESH } \\
\text { WEIGHT } \\
\mathbf{( g )}\end{array}$ & $\begin{array}{c}\text { SAMPLE } \\
\text { FRESH } \\
\text { WEIGHT } \\
\mathbf{( g )}\end{array}$ & $\begin{array}{c}\text { OVEN } \\
\text { DRY } \\
\text { WEIGHT } \\
\mathbf{( g )}\end{array}$ & $\begin{array}{c}\text { TOTAL } \\
\text { DRY } \\
\text { WEIGH } \\
\text { T } \\
\mathbf{( g )}\end{array}$ & $\begin{array}{c}\text { BIOMASS } \\
\text { DENSITY } \\
\text { (Mg/ha) }\end{array}$ & $\begin{array}{c}\text { CARBON } \\
\text { DENSITY } \\
\text { (Mg/ha) }\end{array}$ \\
\hline BeG1 & 290 & 290 & 201 & 0.20 & 2.01 & 0.90 \\
BeG2 & 825 & 300 & 168 & 0.46 & 4.62 & 2.08 \\
BeG3 & 475 & 300 & 239 & 0.38 & 3.78 & 1.70 \\
BeG4 & 340 & 300 & 200 & 0.23 & 2.27 & 1.02 \\
BeG5 & 325 & 300 & 159 & 0.17 & 1.72 & 0.78 \\
BeG6 & 360 & 250 & 139 & 0.20 & 2.00 & 0.90 \\
BeG7 & 160 & 160 & 108 & 0.11 & 1.08 & 0.49 \\
BeG8 & 300 & 300 & 260 & 0.26 & 2.60 & 1.17 \\
BeG9 & 1080 & 300 & 185 & 0.67 & 6.66 & 3.00 \\
BeG10 & 1660 & 290 & 154 & 0.88 & 8.82 & 3.97 \\
Mean & $\mathbf{5 8 1 . 5 0}$ & $\mathbf{2 7 9 . 0 0}$ & $\mathbf{1 8 1 . 3 0}$ & $\mathbf{0 . 3 6}$ & $\mathbf{3 . 5 6}$ & $\mathbf{1 . 6 0}$ \\
\hline
\end{tabular}


Table 7. Biomass and carbon densities of sampling points in grasslands of Barangay Tactac, Imugan, Nueva Vizcaya.

\begin{tabular}{ccccccc}
\hline $\begin{array}{c}\text { SAMPLE } \\
\text { CODE }\end{array}$ & $\begin{array}{c}\text { TOTAL } \\
\text { FRESH } \\
\text { WEIGHT } \\
\text { (g) }\end{array}$ & $\begin{array}{c}\text { SAMPLE } \\
\text { FRESH } \\
\text { WEIGHT } \\
\mathbf{( g )}\end{array}$ & $\begin{array}{c}\text { OVEN } \\
\text { DRY } \\
\text { WEIGHT } \\
\mathbf{( g )}\end{array}$ & $\begin{array}{c}\text { TOTAL } \\
\text { DRY } \\
\text { WEIGHT } \\
\mathbf{( g )}\end{array}$ & $\begin{array}{c}\text { BIOMASS } \\
\text { DENSITY } \\
\text { (Mg/ha) }\end{array}$ & $\begin{array}{c}\text { CARBON } \\
\text { DENSITY } \\
\text { (Mg/ha) }\end{array}$ \\
\hline TG1 & 940 & 300 & 146 & 0.46 & 4.57 & 2.06 \\
TG2 & 1220 & 300 & 188 & 0.76 & 7.65 & 3.44 \\
TG3 & 1010 & 300 & 151 & 0.51 & 5.08 & 2.29 \\
TG4 & 790 & 300 & 148 & 0.39 & 3.90 & 1.75 \\
TG5 & 730 & 300 & 174 & 0.42 & 4.23 & 1.91 \\
TG6 & 1250 & 300 & 197 & 0.82 & 8.21 & 3.69 \\
TG7 & 1800 & 230 & 143 & 1.12 & 11.19 & 5.04 \\
TG8 & 1100 & 300 & 219 & 0.80 & 8.03 & 3.61 \\
TG9 & 650 & 300 & 181 & 0.39 & 3.92 & 1.76 \\
TG10 & 2160 & 300 & 212 & 1.53 & 15.26 & 6.87 \\
Mean & $\mathbf{1 1 6 5 . 0 0}$ & $\mathbf{2 9 3 . 0 0}$ & $\mathbf{1 7 5 . 9 0}$ & $\mathbf{0 . 7 2}$ & $\mathbf{7 . 2 1}$ & $\mathbf{3 . 2 4}$ \\
\hline
\end{tabular}

Table 8. Biomass and carbon densities of sampling points in grasslands of Barangay Atbu, Imugan, Nueva Vizcaya.

\begin{tabular}{ccccccc}
\hline $\begin{array}{c}\text { SAMPLE } \\
\text { CODE }\end{array}$ & $\begin{array}{c}\text { TOTAL } \\
\text { FRESH } \\
\text { WEIGHT } \\
\mathbf{( g )}\end{array}$ & $\begin{array}{c}\text { SAMPLE } \\
\text { FRESH } \\
\text { WEIGHT } \\
\mathbf{( g )}\end{array}$ & $\begin{array}{c}\text { OVEN } \\
\text { DRY } \\
\text { WEIGHT } \\
\mathbf{( g )}\end{array}$ & $\begin{array}{c}\text { TOTAL } \\
\text { DRY } \\
\text { WEIGHT } \\
\mathbf{( g )}\end{array}$ & $\begin{array}{c}\text { BIOMASS } \\
\text { DENSITY } \\
\mathbf{( M g} / \mathbf{h a})\end{array}$ & $\begin{array}{c}\text { CARBON } \\
\text { DENSITY } \\
\text { (Mg/ha) }\end{array}$ \\
\hline AtG1 & 575 & 300 & 158 & 0.30 & 3.03 & 1.36 \\
AtG2 & 450 & 300 & 189 & 0.28 & 2.84 & 1.28 \\
AtG3 & 940 & 300 & 145 & 0.45 & 4.54 & 2.04 \\
AtG4 & 190 & 190 & 152 & 0.15 & 1.52 & 0.68 \\
AtG5 & 1010 & 300 & 89 & 0.30 & 3.00 & 1.35 \\
AtG6 & 525 & 250 & 129 & 0.27 & 2.71 & 1.22 \\
AtG7 & 490 & 300 & 161 & 0.26 & 2.63 & 1.18 \\
AtG8 & 740 & 280 & 99 & 0.26 & 2.62 & 1.18 \\
AtG9 & 805 & 300 & 152 & 0.41 & 4.08 & 1.84 \\
AtG10 & 1310 & 300 & 182 & 0.79 & 7.95 & 3.58 \\
Mean & $\mathbf{7 0 3 . 5 0}$ & $\mathbf{2 8 2 . 0 0}$ & $\mathbf{1 4 5 . 6 0}$ & $\mathbf{0 . 3 5}$ & $\mathbf{3 . 4 9}$ & $\mathbf{1 . 5 7}$ \\
\hline
\end{tabular}


Table 9. Biomass and carbon densities of sampling points in grasslands of Barangay Sta. Rosa, Imugan, Nueva Vizcaya

\begin{tabular}{ccccccc}
\hline $\begin{array}{c}\text { SAMPLE } \\
\text { CODE }\end{array}$ & $\begin{array}{c}\text { TOTAL } \\
\text { FRESH } \\
\text { WEIGHT } \\
\text { (g) }\end{array}$ & $\begin{array}{c}\text { SAMPLE } \\
\text { FRESH } \\
\text { WEIGHT } \\
\mathbf{( g )}\end{array}$ & $\begin{array}{c}\text { OVEN } \\
\text { DRY } \\
\text { WEIGHT } \\
\text { (g) }\end{array}$ & $\begin{array}{c}\text { TOTAL } \\
\text { DRY } \\
\text { WEIGHT } \\
\mathbf{( g )}\end{array}$ & $\begin{array}{c}\text { BIOMASS } \\
\text { DENSITY } \\
\text { (Mg/ha) }\end{array}$ & $\begin{array}{c}\text { CARBON } \\
\text { DENSITY } \\
\text { (Mg/ha) }\end{array}$ \\
\hline SRG1 & 440 & 300 & 169 & 0.25 & 2.48 & 1.12 \\
SRG2 & 990 & 300 & 119 & 0.39 & 3.93 & 1.77 \\
SRG3 & 1440 & 300 & 171 & 0.82 & 8.21 & 3.69 \\
SRG4 & 2110 & 300 & 185 & 1.30 & 13.01 & 5.86 \\
SRG5 & 1920 & 300 & 205 & 1.31 & 13.12 & 5.90 \\
SRG6 & 460 & 300 & 169 & 0.26 & 2.59 & 1.17 \\
SRG7 & 1870 & 130 & 110 & 1.58 & 15.82 & 7.12 \\
SRG8 & 1390 & 300 & 117 & 0.54 & 5.42 & 2.44 \\
SRG9 & 630 & 300 & 109 & 0.23 & 2.29 & 1.03 \\
SRG10 & 560 & 300 & 227 & 0.42 & 4.24 & 1.91 \\
Mean & $\mathbf{1 1 8 1 . 0 0}$ & $\mathbf{2 8 3 . 0 0}$ & $\mathbf{1 5 8 . 1 0}$ & $\mathbf{0 . 7 1}$ & $\mathbf{7 . 1 1}$ & $\mathbf{3 . 2 0}$ \\
\hline
\end{tabular}

Table 10. Biomass and carbon densities of sampling points in grasslands of Barangay Kapinyahan, Imugan, Nueva Vizcaya.

\begin{tabular}{ccccccc}
\hline $\begin{array}{c}\text { SAMPLE } \\
\text { CODE }\end{array}$ & $\begin{array}{c}\text { TOTAL } \\
\text { FRESH } \\
\text { WEIGHT } \\
\text { (g) }\end{array}$ & $\begin{array}{c}\text { SAMPLE } \\
\text { FRESH } \\
\text { WEIGHT } \\
\mathbf{( g )}\end{array}$ & $\begin{array}{c}\text { OVEN } \\
\text { DRY } \\
\text { WEIGHT } \\
\mathbf{( g )}\end{array}$ & $\begin{array}{c}\text { TOTAL } \\
\text { DRY } \\
\text { WEIGH } \\
\mathbf{T} \\
\mathbf{( g )}\end{array}$ & $\begin{array}{c}\text { BIOMASS } \\
\text { DENSITY } \\
\text { (Mg/ha) }\end{array}$ & $\begin{array}{c}\text { CARBON } \\
\text { DENSITY } \\
\text { (Mg/ha) }\end{array}$ \\
\hline CapG1 & 660 & 300 & 252.5 & 0.56 & 5.56 & 2.50 \\
CapG2 & 610 & 300 & 134.3 & 0.27 & 2.73 & 1.23 \\
CapG3 & 820 & 300 & 195 & 0.53 & 5.33 & 2.40 \\
CapG4 & 900 & 300 & 252 & 0.76 & 7.56 & 3.40 \\
CapG5 & 2170 & 300 & 253.5 & 1.83 & 18.34 & 8.25 \\
CapG6 & 1000 & 260 & 229.8 & 0.88 & 8.84 & 3.98 \\
CapG7 & 2050 & 230 & 224.5 & 2.00 & 20.01 & 9.00 \\
CapG8 & 1530 & 300 & 107 & 0.55 & 5.46 & 2.46 \\
CapG9 & 1780 & 260 & 235.5 & 1.61 & 16.12 & 7.26 \\
CapG10 & 2890 & 300 & 245.5 & 2.36 & 23.65 & 10.64 \\
Mean & $\mathbf{1 4 4 1 . 0 0}$ & $\mathbf{2 8 5 . 0 0}$ & $\mathbf{2 1 2 . 9 6}$ & $\mathbf{1 . 1 4}$ & $\mathbf{1 1 . 3 6}$ & $\mathbf{5 . 1 1}$ \\
\hline
\end{tabular}


Table 11. Biomass and carbon densities of sampling points in grasslands of Barangay Putlan, Imugan, Nueva Vizcaya.

\begin{tabular}{ccccccc}
\hline $\begin{array}{c}\text { SAMPLE } \\
\text { CODE }\end{array}$ & $\begin{array}{c}\text { TOTAL } \\
\text { FRESH } \\
\text { WEIGHT } \\
\text { (g) }\end{array}$ & $\begin{array}{c}\text { SAMPLE } \\
\text { FRESH } \\
\text { WEIGHT } \\
\mathbf{( g )}\end{array}$ & $\begin{array}{c}\text { OVEN } \\
\text { DRY } \\
\text { WEIGHT } \\
\mathbf{( g )}\end{array}$ & $\begin{array}{c}\text { TOTAL } \\
\text { DRY } \\
\text { WEIGHT } \\
\mathbf{( g )}\end{array}$ & $\begin{array}{c}\text { BIOMASS } \\
\text { DENSITY } \\
\mathbf{( M g / h a )}\end{array}$ & $\begin{array}{c}\text { CARBON } \\
\text { DENSITY } \\
\text { (Mg/ha) }\end{array}$ \\
\hline PCG1 & 510 & 300 & 243 & 0.41 & 4.13 & 1.86 \\
PCG2 & 1100 & 300 & 205.5 & 0.75 & 7.54 & 3.39 \\
PCG3 & 1013 & 300 & 162.9 & 0.55 & 5.50 & 2.48 \\
PCG4 & 690 & 300 & 230 & 0.53 & 5.29 & 2.38 \\
PCG5 & 800 & 300 & 203.3 & 0.54 & 5.42 & 2.44 \\
PCG6 & 1200 & 300 & 240.3 & 0.96 & 9.61 & 4.33 \\
PCG7 & 1670 & 300 & 167.4 & 0.93 & 9.32 & 4.19 \\
PCG8 & 1050 & 300 & 280.4 & 0.98 & 9.81 & 4.42 \\
PCG9 & 600 & 300 & 217.5 & 0.44 & 4.35 & 1.96 \\
PCG10 & 1500 & 300 & 222.5 & 1.11 & 11.13 & 5.01 \\
Mean & $\mathbf{1 0 1 3 . 3 0}$ & $\mathbf{3 0 0 . 0 0}$ & $\mathbf{2 1 7 . 2 8}$ & $\mathbf{0 . 7 2}$ & $\mathbf{7 . 2 1}$ & $\mathbf{3 . 2 4}$ \\
\hline
\end{tabular}

Table 12. Carbon content of grassland samples in Barangay Buyasyas, Imugan, Nueva Vizacaya

\begin{tabular}{|c|c|}
\hline SAMPLE CODE & CARBON CONTENT (\%) \\
\hline B6033 & 32.6 \\
\hline B6034 & 33.0 \\
\hline B6035 & 21.4 \\
\hline B6036 & 33.1 \\
\hline B6037 & 37.5 \\
\hline Mean & 31.52 \\
\hline
\end{tabular}

Table 13. Carbon content of grassland samples in Barangay Canabuan, Imugan, Nueva Vizacaya.

\begin{tabular}{|c|c|}
\hline SAMPLE CODE & CARBON CONTENT (\%) \\
\hline B6038 & 34.2 \\
\hline B6039 & 18.1 \\
\hline B6040 & 35.5 \\
\hline B6041 & 26.6 \\
\hline B6042 & 37.5 \\
\hline Mean & 30.38 \\
\hline
\end{tabular}


Table 14. Carbon content of grassland samples in Barangay Canarem, Imugan, Nueva Vizacaya

\begin{tabular}{|c|c|}
\hline SAMPLE CODE & CARBON CONTENT (\%) \\
\hline B6043 & 24.6 \\
\hline B6044 & 25.8 \\
\hline B6045 & 37.5 \\
\hline B6046 & 35.5 \\
\hline B6047 & 35.8 \\
\hline Mean & 31.84 \\
\hline
\end{tabular}

Table 15. Carbon content of grassland samples in Barangay Anayo, Imugan, Nueva Vizacaya.

\section{SAMPLE CODE $\quad$ CARBON CONTENT (\%)}

\begin{tabular}{lc}
\hline B6048 & 34.5 \\
B6049 & 31.6 \\
B6050 & 36.6 \\
B6051 & 32.8 \\
B6052 & 37.4 \\
Mean & $\mathbf{3 4 . 5 8}$ \\
\hline
\end{tabular}

Table 16. Carbon content of grassland samples in Barangay Balete, Sta. Fe, Nueva Vizacaya

\begin{tabular}{|c|c|}
\hline SAMPLE CODE & CARBON CONTENT (\%) \\
\hline B6053 & 14.3 \\
\hline B6054 & 31.0 \\
\hline B6055 & 14.1 \\
\hline B6056 & 21.0 \\
\hline B6057 & 29.7 \\
\hline Mean & 22.02 \\
\hline
\end{tabular}

Table 17. Carbon content of grassland samples in Barangay Balete, Aritao, Nueva Vizacaya.

\begin{tabular}{|c|c|}
\hline SAMPLE CODE & CARBON CONTENT (\%) \\
\hline B6058 & 32.2 \\
\hline B6059 & 39.5 \\
\hline B6060 & 40.1 \\
\hline B6061 & 29.9 \\
\hline B6062 & 30.6 \\
\hline Mean & 34.46 \\
\hline
\end{tabular}


Table 18. Carbon content of grassland samples in Tactac, Imugan, Nueva Vizacaya.

\begin{tabular}{|c|c|}
\hline SAMPLE CODE & CARBON CONTENT (\%) \\
\hline B6063 & 42.7 \\
\hline B6064 & 43.2 \\
\hline B 6065 & 42.2 \\
\hline B6066 & 34.4 \\
\hline B6067 & 36.6 \\
\hline Mean & 39.82 \\
\hline
\end{tabular}

Table 19. Carbon content of grassland samples in Barangay Atbu, Imugan, Nueva Vizacaya.

\begin{tabular}{|c|c|}
\hline SAMPLE CODE & CARBON CONTENT (\%) \\
\hline B6068 & 37.8 \\
\hline B6069 & 42.3 \\
\hline B6070 & 40.0 \\
\hline B6071 & 40.0 \\
\hline B6072 & 37.2 \\
\hline Mean & 39.46 \\
\hline
\end{tabular}

Table 20. Carbon content of grassland samples in Barangay Sta. Rosa, Imugan, Nueva Vizacaya.

\begin{tabular}{|c|c|}
\hline SAMPLE CODE & CARBON CONTENT (\%) \\
\hline B6073 & 42.2 \\
\hline B6074 & 31.9 \\
\hline B 6075 & 35.6 \\
\hline B6076 & 37.8 \\
\hline B6077 & 39.7 \\
\hline Mean & 37.44 \\
\hline
\end{tabular}

Table 21. Carbon content of grassland samples in Barangay Kapinyahan, Imugan, Nueva Vizacaya

\begin{tabular}{|c|c|}
\hline SAMPLE CODE & CARBON CONTENT (\%) \\
\hline B6078 & 36.5 \\
\hline B6079 & 31.5 \\
\hline B6080 & 36.3 \\
\hline B6081 & 37.8 \\
\hline B6082 & 33.1 \\
\hline Mean & 35.04 \\
\hline
\end{tabular}


Table 22. Carbon content of grassland samples in Barangay Putlan, Imugan, Nueva Vizacaya.

\begin{tabular}{|c|c|}
\hline SAMPLE CODE & CARBON CONTENT (\%) \\
\hline B6083 & 41.2 \\
\hline B6084 & 39.0 \\
\hline B6085 & 40.1 \\
\hline B6086 & 32.2 \\
\hline B6087 & 39.9 \\
\hline Mean & 38.48 \\
\hline
\end{tabular}

Table 23. Soil bulk and carbon densities of grassland areas in Barangay Buyasyas, Nueva Vizcaya.

\begin{tabular}{ccccccc}
\hline CODE & HEIGHT & VOLUME & $\begin{array}{c}\text { FINAL } \\
\text { ODW } \\
(\mathbf{g})\end{array}$ & $\begin{array}{c}\text { BULK } \\
\text { DENSITY } \\
(\mathbf{g} / \mathbf{c c})\end{array}$ & $\begin{array}{c}\text { SOC } \\
\mathbf{( \% )}\end{array}$ & $\begin{array}{c}\text { CARBON } \\
\text { DENSITY } \\
\mathbf{( M g} / \mathbf{h a})\end{array}$ \\
\hline B1 & 5.0 & 1000 & 101.00 & 0.9156 & 5.05 & 46.24 \\
B2 & 5.0 & 1000 & 94.00 & 0.8521 & 5.05 & 43.03 \\
B3 & 5.0 & 1000 & 98.00 & 0.8884 & 5.05 & 44.86 \\
B4 & 5.0 & 1000 & 89.00 & 0.8068 & 5.05 & 40.74 \\
B5 & 5.0 & 1000 & 68.00 & 0.6164 & 5.45 & 33.60 \\
B6 & 5.0 & 1000 & 43.00 & 0.3898 & 5.45 & 21.24 \\
B7 & 5.0 & 1000 & 80.00 & 0.7252 & 5.45 & 39.53 \\
B8 & 5.0 & 1000 & 100.00 & 0.9065 & 5.45 & 49.41 \\
B9 & 5.0 & 1000 & 101.00 & 0.9156 & 3.82 & 34.98 \\
B10 & 5.0 & 1000 & 128.00 & 1.1604 & 3.82 & 44.33 \\
B11 & 5.0 & 1000 & 121.00 & 1.0969 & 3.82 & 41.90 \\
B12 & 5.0 & 1000 & 110.00 & 0.9972 & 3.82 & 38.09 \\
B13 & 5.0 & 1000 & 119.00 & 1.0788 & 3.97 & 42.83 \\
B14 & 5.0 & 1000 & 120.00 & 1.0878 & 3.97 & 43.19 \\
B15 & 5.0 & 1000 & 121.00 & 1.0969 & 3.97 & 43.55 \\
B16 & 5.0 & 1000 & 75.00 & 0.6799 & 3.97 & 26.99 \\
B17 & 5.0 & 1000 & 115.00 & 1.0425 & 3.85 & 40.14 \\
B18 & 5.0 & 1000 & 94.00 & 0.8521 & 3.85 & 32.81 \\
B19 & 5.0 & 1000 & 94.00 & 0.8521 & 3.85 & 32.81 \\
B20 & 5.0 & 1000 & 97.00 & 0.8793 & 3.85 & 33.85 \\
Mean & 5.0 & $\mathbf{1 0 0 0}$ & $\mathbf{9 8 . 4 0}$ & $\mathbf{0 . 8 9 2 0}$ & $\mathbf{4 . 4 3}$ & $\mathbf{3 8 . 7 1}$ \\
\hline
\end{tabular}


Table 24. Soil bulk and carbon densities of grassland areas in Barangay Canabuan, Nueva Vizcaya.

\begin{tabular}{ccccccc}
\hline CODE & $\begin{array}{c}\text { HEIGHT } \\
(\mathbf{c m})\end{array}$ & VOLUME & $\begin{array}{c}\text { FINAL } \\
\text { ODW } \\
\mathbf{( g )}\end{array}$ & $\begin{array}{c}\text { BULK } \\
\text { DENSITY } \\
\mathbf{( g / c c )}\end{array}$ & $\begin{array}{c}\text { SOC } \\
\mathbf{( \% )}\end{array}$ & $\begin{array}{c}\text { CARBON } \\
\text { DENSITY } \\
\mathbf{( M g / h a})\end{array}$ \\
\hline C1 & 5.0 & 1000 & 108.00 & 0.9791 & 3.84 & 37.60 \\
C2 & 5.0 & 1000 & 107.00 & 0.9700 & 3.84 & 37.25 \\
C3 & 5.0 & 1000 & 109.00 & 0.9881 & 3.84 & 37.94 \\
C4 & 5.0 & 1000 & 119.00 & 1.0788 & 3.84 & 41.43 \\
C5 & 5.0 & 1000 & 95.00 & 0.8612 & 4.03 & 34.71 \\
C6 & 5.0 & 1000 & 79.00 & 0.7162 & 4.03 & 28.86 \\
C7 & 5.0 & 1000 & 118.00 & 1.0697 & 4.03 & 43.11 \\
C8 & 5.0 & 1000 & 103.00 & 0.9337 & 4.03 & 37.63 \\
C9 & 5.0 & 1000 & 127.00 & 1.1513 & 3.90 & 44.90 \\
C10 & 5.0 & 1000 & 111.50 & 1.0108 & 3.90 & 39.42 \\
C11 & 5.0 & 1000 & 99.00 & 0.8975 & 3.90 & 35.00 \\
C12 & 5.0 & 1000 & 111.00 & 1.0063 & 3.90 & 39.24 \\
C13 & 5.0 & 1000 & 91.00 & 0.8250 & 4.53 & 37.37 \\
C14 & 5.0 & 1000 & 99.00 & 0.8975 & 4.53 & 40.66 \\
C15 & 5.0 & 1000 & 109.00 & 0.9881 & 4.53 & 44.76 \\
C16 & 5.0 & 1000 & 102.00 & 0.9247 & 4.53 & 41.89 \\
C17 & 5.0 & 1000 & 101.00 & 0.9156 & 3.74 & 34.24 \\
C18 & 5.0 & 1000 & 91.00 & 0.8250 & 3.74 & 30.85 \\
C19 & 5.0 & 1000 & 110.00 & 0.9972 & 3.74 & 37.30 \\
C20 & 5.0 & 1000 & 101.00 & 0.9156 & 3.74 & 34.24 \\
Mean & 5.0 & $\mathbf{1 0 0 0}$ & $\mathbf{1 0 4 . 5 3}$ & $\mathbf{0 . 9 4 7 6}$ & $\mathbf{4 . 0 1}$ & $\mathbf{3 7 . 9 2}$ \\
\hline & & & & & & \\
\hline
\end{tabular}

Table 25.Soil bulk and carbon densities of grassland areas in Barangay Canarem, Nueva Vizcaya.

\begin{tabular}{ccccccc}
\hline CODE & $\begin{array}{c}\text { HEIGHT } \\
\mathbf{( c m )}\end{array}$ & VOLUME & $\begin{array}{c}\text { FINAL } \\
\text { ODW } \\
\mathbf{( g )}\end{array}$ & $\begin{array}{c}\text { BULK } \\
\text { DENSITY } \\
\mathbf{( g / c c})\end{array}$ & $\begin{array}{c}\text { SOC } \\
\mathbf{( \% )}\end{array}$ & $\begin{array}{c}\text { CARBON } \\
\text { DENSITY } \\
\mathbf{( M g / h a})\end{array}$ \\
\hline CA1 & 5.0 & 1000 & 118.00 & 1.0697 & 4.42 & 47.28 \\
CA2 & 5.0 & 1000 & 109.00 & 0.9881 & 4.42 & 43.68 \\
CA3 & 5.0 & 1000 & 104.00 & 0.9428 & 4.42 & 41.67 \\
CA4 & 5.0 & 1000 & 118.00 & 1.0697 & 4.42 & 47.28 \\
CA5 & 5.0 & 1000 & 121.00 & 1.0969 & 3.81 & 41.79 \\
CA6 & 5.0 & 1000 & 122.00 & 1.1060 & 3.81 & 42.14 \\
CA7 & 5.0 & 1000 & 98.00 & 0.8884 & 3.81 & 33.85 \\
CA8 & 5.0 & 1000 & 137.00 & 1.2420 & 3.81 & 47.32 \\
CA9 & 5.0 & 1000 & 102.00 & 0.9247 & 4.75 & 43.92
\end{tabular}




\begin{tabular}{lllllll} 
CA10 & 5.0 & 1000 & 112.00 & 1.0153 & 4.75 & 48.23 \\
CA11 & 5.0 & 1000 & 118.00 & 1.0697 & 4.75 & 50.81 \\
CA12 & 5.0 & 1000 & 103.00 & 0.9337 & 4.75 & 44.35 \\
CA13 & 5.0 & 1000 & 109.00 & 0.9881 & 4.68 & 46.24 \\
CA14 & 5.0 & 1000 & 109.00 & 0.9881 & 4.68 & 46.24 \\
CA15 & 5.0 & 1000 & 100.00 & 0.9065 & 4.68 & 42.43 \\
CA16 & 5.0 & 1000 & 121.00 & 1.0969 & 4.68 & 51.34 \\
CA17 & 5.0 & 1000 & 99.00 & 0.8975 & 4.45 & 39.94 \\
CA18 & 5.0 & 1000 & 103.00 & 0.9337 & 4.45 & 41.55 \\
CA19 & 5.0 & 1000 & 104.00 & 0.9428 & 4.45 & 41.95 \\
CA20 & 5.0 & 1000 & 104.00 & 0.9428 & 4.45 & 41.95 \\
Mean & $\mathbf{5 . 0}$ & $\mathbf{1 0 0 0}$ & $\mathbf{1 1 0 . 5 5}$ & $\mathbf{1 . 0 0 2 2}$ & $\mathbf{4 . 4 2}$ & $\mathbf{4 4 . 2 0}$ \\
\hline
\end{tabular}

Table 26. Soil bulk and carbon densities of grassland areas in Barangay Anayo, Nueva Vizcaya

\begin{tabular}{ccccccc}
\hline CODE & $\begin{array}{c}\text { HEIGHT } \\
(\mathbf{c m})\end{array}$ & VOLUME & $\begin{array}{c}\text { FINAL } \\
\text { ODW } \\
\mathbf{( g )}\end{array}$ & $\begin{array}{c}\text { BULK } \\
\text { DENSITY } \\
\mathbf{( g / c c )}\end{array}$ & $\begin{array}{c}\text { SOC } \\
\mathbf{( \% )}\end{array}$ & $\begin{array}{c}\text { CARBON } \\
\text { DENSITY } \\
\mathbf{( M g / h a}\end{array}$ \\
\hline A1 & 5.0 & 1000 & 103.86 & 0.9415 & 4.69 & 44.16 \\
A2 & 5.0 & 1000 & 111.64 & 1.0121 & 4.69 & 47.47 \\
A3 & 5.0 & 1000 & 119.39 & 1.0823 & 4.69 & 50.76 \\
A4 & 5.0 & 1000 & 107.05 & 0.9705 & 4.69 & 45.51 \\
A5 & 5.0 & 1000 & 105.30 & 0.9546 & 5.60 & 53.46 \\
A6 & 5.0 & 1000 & 70.00 & 0.6346 & 5.60 & 35.54 \\
A7 & 5.0 & 1000 & 105.68 & 0.9580 & 5.60 & 53.65 \\
A8 & 5.0 & 1000 & 109.30 & 0.9908 & 5.60 & 55.49 \\
A9 & 5.0 & 1000 & 105.30 & 0.9546 & 4.07 & 38.85 \\
A10 & 5.0 & 1000 & 86.03 & 0.7799 & 4.07 & 31.74 \\
A11 & 5.0 & 1000 & 98.10 & 0.8893 & 4.07 & 36.20 \\
A12 & 5.0 & 1000 & 96.26 & 0.8726 & 4.07 & 35.52 \\
A13 & 5.0 & 1000 & 95.53 & 0.8660 & 5.85 & 50.66 \\
A14 & 5.0 & 1000 & 93.00 & 0.8431 & 5.85 & 49.32 \\
A15 & 5.0 & 1000 & 87.72 & 0.7952 & 5.85 & 46.52 \\
A16 & 5.0 & 1000 & 87.15 & 0.7901 & 5.85 & 46.22 \\
A17 & 5.0 & 1000 & 104.35 & 0.9460 & 5.39 & 50.99 \\
A18 & 5.0 & 1000 & 99.25 & 0.8997 & 5.39 & 48.50 \\
A19 & 5.0 & 1000 & 91.09 & 0.8258 & 5.39 & 44.51 \\
A20 & 5.0 & 1000 & 103.51 & 0.9384 & 5.39 & 50.58 \\
Mean & 5.0 & $\mathbf{1 0 0 0}$ & $\mathbf{9 8 . 9 8}$ & $\mathbf{0 . 8 9 7 3}$ & 5.12 & $\mathbf{4 5 . 7 8}$ \\
\hline
\end{tabular}


Table 27. Soil bulk and carbon densities of grassland areas in Barangay Balete, Sta. Fe, Nueva

Vizcaya.

\begin{tabular}{ccccccc}
\hline CODE & $\begin{array}{c}\text { HEIGHT } \\
(\mathbf{c m})\end{array}$ & VOLUME & $\begin{array}{c}\text { FINAL } \\
\text { ODW } \\
\mathbf{( g )}\end{array}$ & $\begin{array}{c}\text { BULK } \\
\text { DENSITY } \\
\mathbf{( g / c c})\end{array}$ & $\begin{array}{c}\text { SOC } \\
\mathbf{( \% )}\end{array}$ & $\begin{array}{c}\text { CARBON } \\
\text { DENSITY } \\
(\mathbf{M g} / \mathbf{h a})\end{array}$ \\
\hline BA1 & 5.0 & 1000 & 174.51 & 1.5820 & 4.33 & 68.50 \\
BA2 & 5.0 & 1000 & 138.97 & 1.2598 & 4.33 & 54.55 \\
BA3 & 5.0 & 1000 & 115.61 & 1.0481 & 4.33 & 45.38 \\
BA4 & 5.0 & 1000 & 108.40 & 0.9827 & 4.33 & 42.55 \\
BA5 & 5.0 & 1000 & 69.62 & 0.6311 & 4.97 & 31.37 \\
BA6 & 5.0 & 1000 & 106.14 & 0.9622 & 4.97 & 47.82 \\
BA7 & 5.0 & 1000 & 120.01 & 1.0879 & 4.97 & 54.07 \\
BA8 & 5.0 & 1000 & 113.37 & 1.0277 & 4.97 & 51.08 \\
BA9 & 5.0 & 1000 & 110.01 & 0.9973 & 5.44 & 54.25 \\
BA10 & 5.0 & 1000 & 99.56 & 0.9026 & 5.44 & 49.10 \\
BA11 & 5.0 & 1000 & 122.42 & 1.1098 & 5.44 & 60.37 \\
BA12 & 5.0 & 1000 & 128.32 & 1.1633 & 5.44 & 63.28 \\
BA13 & 5.0 & 1000 & 97.76 & 0.8862 & 5.16 & 45.73 \\
BA14 & 5.0 & 1000 & 124.30 & 1.1268 & 5.16 & 58.14 \\
BA15 & 5.0 & 1000 & 115.56 & 1.0476 & 5.16 & 54.06 \\
BA16 & 5.0 & 1000 & 106.24 & 0.9631 & 5.16 & 49.70 \\
BA17 & 5.0 & 1000 & 110.54 & 1.0021 & 5.10 & 51.11 \\
BA18 & 5.0 & 1000 & 108.50 & 0.9836 & 5.10 & 50.16 \\
BA19 & 5.0 & 1000 & 106.90 & 0.9691 & 5.10 & 49.42 \\
BA20 & 5.0 & 1000 & 106.09 & 0.9617 & 5.10 & 49.05 \\
Mean & 5.0 & $\mathbf{1 0 0 0}$ & $\mathbf{1 1 4 . 1 4}$ & $\mathbf{1 . 0 3 4 7}$ & 5.00 & 51.48 \\
\hline
\end{tabular}

Table 28. Soil bulk and carbon densities of grassland areas in Barangay Balete, Aritao, Nueva Vizcaya.

\begin{tabular}{ccccccc}
\hline CODE & $\begin{array}{c}\text { HEIGHT } \\
\mathbf{( c m )}\end{array}$ & VOLUME & $\begin{array}{c}\text { FINAL } \\
\text { ODW (g) }\end{array}$ & $\begin{array}{c}\text { BULK } \\
\text { DENSITY } \\
\text { (g/cc) }\end{array}$ & SOC (\%) & $\begin{array}{c}\text { CARBON } \\
\text { DENSITY } \\
\text { (Mg/ha) }\end{array}$ \\
\hline BE1 & 5.0 & 1000 & 80.22 & 0.7272 & 3.99 & 29.02 \\
BE2 & 5.0 & 1000 & 106.79 & 0.9681 & 3.99 & 38.63 \\
BE3 & 5.0 & 1000 & 120.44 & 1.0918 & 3.99 & 43.56 \\
BE4 & 5.0 & 1000 & 96.28 & 0.8728 & 3.99 & 34.83 \\
BE5 & 5.0 & 1000 & 97.14 & 0.8806 & 2.01 & 17.70 \\
BE6 & 5.0 & 1000 & 124.59 & 1.1295 & 2.01 & 22.70 \\
BE7 & 5.0 & 1000 & 119.07 & 1.0794 & 2.01 & 21.70 \\
BE8 & 5.0 & 1000 & 104.08 & 0.9435 & 2.01 & 18.96 \\
BE9 & 5.0 & 1000 & 114.54 & 1.0384 & 4.00 & 41.53
\end{tabular}




\begin{tabular}{lllllll} 
BE10 & 5.0 & 1000 & 109.24 & 0.9903 & 4.00 & 39.61 \\
BE11 & 5.0 & 1000 & 143.56 & 1.3014 & 4.00 & 52.06 \\
BE12 & 5.0 & 1000 & 124.24 & 1.1263 & 4.00 & 45.05 \\
BE13 & 5.0 & 1000 & 106.38 & 0.9644 & 3.32 & 32.02 \\
BE14 & 5.0 & 1000 & 71.59 & 0.6490 & 3.32 & 21.55 \\
BE15 & 5.0 & 1000 & 102.46 & 0.9288 & 3.32 & 30.84 \\
BE16 & 5.0 & 1000 & 120.35 & 1.0910 & 3.32 & 36.22 \\
BE17 & 5.0 & 1000 & 102.30 & 0.9274 & 4.58 & 42.47 \\
BE18 & 5.0 & 1000 & 110.38 & 1.0006 & 4.58 & 45.83 \\
BE19 & 5.0 & 1000 & 114.54 & 1.0384 & 4.58 & 47.56 \\
BE20 & 5.0 & 1000 & 109.24 & 0.9903 & 4.58 & 45.36 \\
Mean & $\mathbf{5 . 0}$ & $\mathbf{1 0 0 0}$ & $\mathbf{1 0 8 . 8 7}$ & $\mathbf{0 . 9 8 7 0}$ & $\mathbf{3 . 5 8}$ & $\mathbf{3 5 . 3 6}$ \\
\hline
\end{tabular}

Table 29. Soil bulk and carbon densities of grassland areas in Barangay Tactac, Nueva Vizcaya.

\begin{tabular}{ccccccc}
\hline CODE & $\begin{array}{c}\text { HEIGHT } \\
(\mathbf{c m})\end{array}$ & VOLUME & $\begin{array}{c}\text { FINAL } \\
\text { ODW } \\
\mathbf{( g )}\end{array}$ & $\begin{array}{c}\text { BULK } \\
\text { DENSITY } \\
\mathbf{( g / c c )}\end{array}$ & $\begin{array}{c}\text { SOC } \\
\mathbf{( \% )}\end{array}$ & $\begin{array}{c}\text { CARBON } \\
\text { DENSITY } \\
\mathbf{( M g} / \mathbf{h a})\end{array}$ \\
\hline $\mathrm{T} 1$ & 5.0 & 1000 & 90.91 & 0.8241 & 5.81 & 47.88 \\
$\mathrm{~T} 2$ & 5.0 & 1000 & 81.46 & 0.7385 & 5.81 & 42.90 \\
$\mathrm{~T} 3$ & 5.0 & 1000 & 62.17 & 0.5636 & 5.81 & 32.74 \\
$\mathrm{~T} 4$ & 5.0 & 1000 & 85.12 & 0.7716 & 5.81 & 44.83 \\
$\mathrm{~T} 5$ & 5.0 & 1000 & 83.27 & 0.7549 & 4.66 & 35.18 \\
$\mathrm{~T} 6$ & 5.0 & 1000 & 84.53 & 0.7663 & 4.66 & 35.71 \\
$\mathrm{~T} 7$ & 5.0 & 1000 & 79.70 & 0.7225 & 4.66 & 33.67 \\
$\mathrm{~T} 8$ & 5.0 & 1000 & 92.62 & 0.8396 & 4.66 & 39.13 \\
$\mathrm{~T} 9$ & 5.0 & 1000 & 65.37 & 0.5926 & 5.78 & 34.25 \\
$\mathrm{~T} 10$ & 5.0 & 1000 & 87.85 & 0.7964 & 5.78 & 46.03 \\
$\mathrm{~T} 11$ & 5.0 & 1000 & 86.78 & 0.7867 & 5.78 & 45.47 \\
$\mathrm{~T} 12$ & 5.0 & 1000 & 78.77 & 0.7141 & 5.78 & 41.27 \\
$\mathrm{~T} 13$ & 5.0 & 1000 & 90.70 & 0.8222 & 6.06 & 49.83 \\
$\mathrm{~T} 14$ & 5.0 & 1000 & 90.70 & 0.8222 & 6.06 & 49.83 \\
$\mathrm{~T} 15$ & 5.0 & 1000 & 83.27 & 0.7549 & 6.06 & 45.75 \\
$\mathrm{~T} 16$ & 5.0 & 1000 & 86.68 & 0.7858 & 6.06 & 47.62 \\
$\mathrm{~T} 17$ & 5.0 & 1000 & 82.76 & 0.7503 & 5.24 & 39.31 \\
$\mathrm{~T} 18$ & 5.0 & 1000 & 75.70 & 0.6863 & 5.24 & 35.96 \\
$\mathrm{~T} 19$ & 5.0 & 1000 & 89.52 & 0.8115 & 5.24 & 42.52 \\
$\mathrm{~T} 20$ & 5.0 & 1000 & 77.01 & 0.6981 & 5.24 & 36.58 \\
Mean & 5.0 & $\mathbf{1 0 0 0}$ & $\mathbf{8 2 . 7 4}$ & $\mathbf{0 . 7 5 0 1}$ & $\mathbf{5 . 5 1}$ & $\mathbf{4 1 . 3 2}$ \\
\hline
\end{tabular}


Table 30. Soil bulk and carbon densities of grassland areas in Barangay Atbu, Nueva Vizcaya.

\begin{tabular}{|c|c|c|c|c|c|c|}
\hline CODE & $\begin{array}{c}\text { HEIGHT } \\
(\mathrm{cm})\end{array}$ & VOLUME & $\begin{array}{c}\text { FINAL } \\
\text { ODW (g) }\end{array}$ & $\begin{array}{c}\text { BULK } \\
\text { DENSITY } \\
(\mathrm{g} / \mathrm{cc}) \\
\end{array}$ & SOC (\%) & $\begin{array}{c}\text { CARBON } \\
\text { DENSITY } \\
\text { (Mg/ha) }\end{array}$ \\
\hline AT1 & 5.0 & 1000 & 68.00 & 0.6164 & 3.48 & 21.45 \\
\hline AT2 & 5.0 & 1000 & 98.00 & 0.8884 & 3.48 & 30.92 \\
\hline AT3 & 5.0 & 1000 & 99.00 & 0.8975 & 3.48 & 31.23 \\
\hline AT4 & 5.0 & 1000 & 91.00 & 0.8250 & 3.48 & 28.71 \\
\hline AT5 & 5.0 & 1000 & 98.00 & 0.8884 & 4.39 & 39.00 \\
\hline AT6 & 5.0 & 1000 & 85.00 & 0.7706 & 4.39 & 33.83 \\
\hline AT7 & 5.0 & 1000 & 109.00 & 0.9881 & 4.39 & 43.38 \\
\hline AT8 & 5.0 & 1000 & 122.00 & 1.1060 & 4.39 & 48.55 \\
\hline AT9 & 5.0 & 1000 & 99.00 & 0.8975 & 3.95 & 35.45 \\
\hline AT10 & 5.0 & 1000 & 95.00 & 0.8612 & 3.95 & 34.02 \\
\hline AT11 & 5.0 & 1000 & 102.00 & 0.9247 & 3.95 & 36.52 \\
\hline AT12 & 5.0 & 1000 & 109.00 & 0.9881 & 3.95 & 39.03 \\
\hline AR13 & 5.0 & 1000 & 96.00 & 0.8703 & 5.16 & 44.91 \\
\hline AT14 & 5.0 & 1000 & 94.00 & 0.8521 & 5.16 & 43.97 \\
\hline AT15 & 5.0 & 1000 & 85.00 & 0.7706 & 5.16 & 39.76 \\
\hline AT16 & 5.0 & 1000 & 115.00 & 1.0425 & 5.16 & 53.79 \\
\hline AT17 & 5.0 & 1000 & 105.00 & 0.9519 & 4.21 & 40.07 \\
\hline AT18 & 5.0 & 1000 & 109.00 & 0.9881 & 4.21 & 41.60 \\
\hline AT19 & 5.0 & 1000 & 90.00 & 0.8159 & 4.21 & 34.35 \\
\hline AT20 & 5.0 & 1000 & 87.00 & 0.7887 & 4.21 & 33.20 \\
\hline Mean & 5.0 & 1000 & 97.80 & 0.8866 & 4.24 & 37.69 \\
\hline
\end{tabular}


Table 31. Soil bulk and carbon densities of grassland areas in Barangay Sta. Rosa, Nueva Vizcaya.

\begin{tabular}{lcccccc}
\hline CODE & $\begin{array}{c}\text { HEIGHT } \\
(\mathbf{c m})\end{array}$ & VOLUME & $\begin{array}{c}\text { FINAL } \\
\text { ODW } \\
\mathbf{( g )}\end{array}$ & $\begin{array}{c}\text { BULK } \\
\text { DENSITY } \\
\mathbf{( g / c c )}\end{array}$ & $\begin{array}{c}\text { SOC } \\
\mathbf{( \% )}\end{array}$ & $\begin{array}{c}\text { CARBON } \\
\text { DENSITY } \\
\mathbf{( M g} / \mathbf{h a})\end{array}$ \\
\hline SR1 & 5.0 & 1000 & 99.51 & 0.9021 & 3.25 & 29.32 \\
SR2 & 5.0 & 1000 & 79.13 & 0.7173 & 3.25 & 23.31 \\
SR3 & 5.0 & 1000 & 89.57 & 0.8120 & 3.25 & 26.39 \\
SR4 & 5.0 & 1000 & 88.83 & 0.8053 & 3.25 & 26.17 \\
SR5 & 5.0 & 1000 & 73.16 & 0.6632 & 7.46 & 49.48 \\
SR6 & 5.0 & 1000 & 80.79 & 0.7324 & 7.46 & 54.64 \\
SR7 & 5.0 & 1000 & 70.75 & 0.6414 & 7.46 & 47.85 \\
SR8 & 5.0 & 1000 & 70.53 & 0.6394 & 7.46 & 47.70 \\
SR9 & 5.0 & 1000 & 83.23 & 0.7545 & 5.69 & 42.93 \\
SR10 & 5.0 & 1000 & 96.40 & 0.8739 & 5.69 & 49.73 \\
SR11 & 5.0 & 1000 & 90.96 & 0.8246 & 5.69 & 46.92 \\
SR12 & 5.0 & 1000 & 85.30 & 0.7733 & 5.69 & 44.00 \\
SR13 & 5.0 & 1000 & 92.71 & 0.8405 & 7.49 & 62.95 \\
SR14 & 5.0 & 1000 & 87.42 & 0.7925 & 7.49 & 59.36 \\
SR15 & 5.0 & 1000 & 80.33 & 0.7282 & 7.49 & 54.54 \\
SR16 & 5.0 & 1000 & 83.95 & 0.7610 & 7.49 & 57.00 \\
SR17 & 5.0 & 1000 & 49.51 & 0.4488 & 8.19 & 36.76 \\
SR18 & 5.0 & 1000 & 42.70 & 0.3871 & 8.19 & 31.70 \\
SR19 & 5.0 & 1000 & 93.45 & 0.8472 & 8.19 & 69.38 \\
SR20 & 5.0 & 1000 & 113.54 & 1.0293 & 8.19 & 84.30 \\
Mean & 5.0 & 1000 & 82.59 & 0.7487 & 6.42 & 47.22 \\
\hline & & & & & &
\end{tabular}


Table 32. Soil bulk and carbon densities of grassland areas in Barangay Kapinyahan, Nueva Vizcaya.

\begin{tabular}{lcccccc}
\hline CODE & $\begin{array}{c}\text { HEIGHT } \\
\mathbf{( c m )}\end{array}$ & VOLUME & $\begin{array}{c}\text { FINAL } \\
\text { ODW (g) }\end{array}$ & $\begin{array}{c}\text { BULK } \\
\text { DENSITY } \\
\mathbf{( g / c c )}\end{array}$ & SOC (\%) & $\begin{array}{c}\text { CARBON } \\
\text { DENSITY } \\
\text { (Mg/ha) }\end{array}$ \\
\hline CP1 & 5.0 & 1000 & 95.00 & 0.8612 & 3.88 & 33.42 \\
CP2 & 5.0 & 1000 & 110.00 & 0.9972 & 3.88 & 38.69 \\
CP3 & 5.0 & 1000 & 105.00 & 0.9519 & 3.88 & 36.93 \\
CP4 & 5.0 & 1000 & 101.00 & 0.9156 & 3.88 & 35.53 \\
CP5 & 5.0 & 1000 & 103.00 & 0.9337 & 5.13 & 47.90 \\
CP6 & 5.0 & 1000 & 87.00 & 0.7887 & 5.13 & 40.46 \\
CP7 & 5.0 & 1000 & 72.00 & 0.6527 & 5.13 & 33.48 \\
CP8 & 5.0 & 1000 & 98.00 & 0.8884 & 5.13 & 45.58 \\
CP9 & 5.0 & 1000 & 86.00 & 0.7796 & 4.61 & 35.94 \\
CP10 & 5.0 & 1000 & 104.00 & 0.9428 & 4.61 & 43.46 \\
CP11 & 5.0 & 1000 & 90.00 & 0.8159 & 4.61 & 37.61 \\
CP12 & 5.0 & 1000 & 94.00 & 0.8521 & 4.61 & 39.28 \\
CP13 & 5.0 & 1000 & 103.00 & 0.9337 & 4.76 & 44.45 \\
CP14 & 5.0 & 1000 & 93.00 & 0.8431 & 4.76 & 40.13 \\
CP15 & 5.0 & 1000 & 112.00 & 1.0153 & 4.76 & 48.33 \\
CP16 & 5.0 & 1000 & 62.00 & 0.5621 & 4.76 & 26.75 \\
CP17 & 5.0 & 1000 & 102.00 & 0.9247 & 4.83 & 44.66 \\
CP18 & 5.0 & 1000 & 99.00 & 0.8975 & 4.83 & 43.35 \\
CP19 & 5.0 & 1000 & 99.00 & 0.8975 & 4.83 & 43.35 \\
CP20 & 5.0 & 1000 & 94.00 & 0.8521 & 4.83 & 41.16 \\
Mean & 5.0 & $\mathbf{1 0 0 0}$ & $\mathbf{9 5 . 4 5}$ & $\mathbf{0 . 8 6 5 3}$ & $\mathbf{4 . 6 4}$ & $\mathbf{4 0 . 0 2}$ \\
\hline
\end{tabular}


Table 33. Soil bulk and carbon densities of grassland areas in Barangay Putlan, Nueva Vizcaya.

\begin{tabular}{ccccccc}
\hline CODE & $\begin{array}{c}\text { HEIGHT } \\
(\mathbf{c m})\end{array}$ & VOLUME & $\begin{array}{c}\text { FINAL } \\
\text { ODW } \\
\text { (g) }\end{array}$ & $\begin{array}{c}\text { BULK } \\
\text { DENSITY } \\
\mathbf{( g / c c )}\end{array}$ & $\begin{array}{c}\text { SOC } \\
\mathbf{( \% )}\end{array}$ & $\begin{array}{c}\text { CARBON } \\
\text { DENSITY } \\
\mathbf{( M g} / \mathbf{h a})\end{array}$ \\
\hline P1 & 5.0 & 1000 & 96.27 & 0.8727 & 3.02 & 26.36 \\
P2 & 5.0 & 1000 & 108.05 & 0.9795 & 3.02 & 29.58 \\
P3 & 5.0 & 1000 & 114.62 & 1.0391 & 3.02 & 31.38 \\
P4 & 5.0 & 1000 & 108.93 & 0.9875 & 3.02 & 29.82 \\
P5 & 5.0 & 1000 & 120.63 & 1.0936 & 3.84 & 41.99 \\
P6 & 5.0 & 1000 & 120.27 & 1.0903 & 3.84 & 41.87 \\
P7 & 5.0 & 1000 & 101.58 & 0.9209 & 3.84 & 35.36 \\
P8 & 5.0 & 1000 & 109.08 & 0.9889 & 3.84 & 37.97 \\
P9 & 5.0 & 1000 & 84.01 & 0.7616 & 3.84 & 29.24 \\
P10 & 5.0 & 1000 & 98.40 & 0.8920 & 3.84 & 34.25 \\
P11 & 5.0 & 1000 & 114.84 & 1.0411 & 3.84 & 39.98 \\
P12 & 5.0 & 1000 & 102.21 & 0.9266 & 3.84 & 35.58 \\
P13 & 5.0 & 1000 & 95.38 & 0.8647 & 4.44 & 38.39 \\
P14 & 5.0 & 1000 & 81.16 & 0.7357 & 4.44 & 32.67 \\
P15 & 5.0 & 1000 & 98.93 & 0.8968 & 4.44 & 39.82 \\
P16 & 5.0 & 1000 & 93.53 & 0.8479 & 4.44 & 37.65 \\
P17 & 5.0 & 1000 & 87.24 & 0.7909 & 4.33 & 34.24 \\
P18 & 5.0 & 1000 & 97.85 & 0.8871 & 4.33 & 38.41 \\
P19 & 5.0 & 1000 & 99.87 & 0.9054 & 4.33 & 39.20 \\
P20 & 5.0 & 1000 & 112.61 & 1.0209 & 4.33 & 44.20 \\
Mean & 5.00 & $\mathbf{1 0 0 0}$ & $\mathbf{1 0 2 . 2 7}$ & $\mathbf{0 . 9 2 7 1}$ & 3.89 & $\mathbf{3 5 . 9 0}$ \\
\hline & & & & & &
\end{tabular}




\section{Working Paper Series}

\section{3-2005}

1. Eco-Certification as an Incentive to Conserve Biodiversity in Rubber Smallholder Agroforestry Systems: A Preliminary Study

2. RUPES: A Review of Initiatives from Developed Countries

3. Development Assistance to Upland Communities in The Philippines

4. Forest Area Rationalization in Indonesia: A Study on The Forest Resource Condition and Policy Reform

5. Environmental Service "Payments": Experiences, Constraints and Potential in The Philippines

6. Assessing the Livelihood Benefits to Local Communities from the Profafor Carbon Sequestration Project, Ecuador

7. An Introduction to the Conceptual Basis of RUPES

8. Review of Developments of Environmental Services Markets in Sri Lanka

9. Rewards for Environmental Services in the Philippines Uplands: Constraints and Opportunities for Institutional Reform

10. Case Study of the Maasin Watershed: Analyzing the Role of Institutions in a Watershed-Use Conflict

11. Rapid Agrobiodiversity Assessment (RABA): A tool to capture the understanding and knowledge of stakeholders on the benefits of agrobiodiversity

12. Rewarding Upland Farmers for Environmental Services: Experience, Constraints, and Potential in Vietnam

13. Institutional Constraints and Opportunities in Developing Environmental Service Markets: Lessons from Institutional Studies on RUPES in Indonesia

14. Review of Developments of Environmental Services Markets in Indonesia

15. RUPES Typology of Environmental Service Worthy of Reward

\section{7}

1. Report on the Self-Evaluation Study of RUPES

1. Participatory poverty and livelihood assessment report, Kalahan, Nueva Vizcaya, the Philippines 


\section{Who we are}

The World Agroforestry Centre is the international leader in the science and practice of integrating 'working trees' on small farms and in rural landscapes. We have invigorated the ancient practice of growing trees on farms, using innovative science for development to transform lives and landscapes.

\section{Our vision}

Our Vision is an 'Agroforestry Transformation' in the developing world resulting in a massive increase in the use of working trees on working landscapes by smallholder rural households that helps ensure security in food, nutrition, income, health, shelter and energy and a regenerated environment.

\section{Our mission}

Our mission is to advance the science and practice of agroforestry to help realize an 'Agroforestry Transformation' throughout the developing world.

\section{F U T URE HA RY/ES T CGIAR}

A Future Harvest Centre supported by the CGIAR

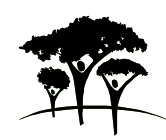

United Nations Avenue, Gigiri - PO Box 30677 - 00100 Nairobi, Kenya Tel: +254 207224000 or via USA +1 6508336645

Fax: +254207224001 or via USA +16508336646

Southeast Asia Regional Programme - Sindang Barang, Bogor 16680 PO Box161 Bogor 16001, Indonesia

Tel: +62 251625415 - Fax: +62 251625416

www.worldagroforestry.org 